ISSN : 1978-4333, Vol. 03, No. 01

4

\title{
Tekanan Penduduk, Overshoot Ekologi Pulau Jawa, dan Masa Pemulihannya
}

Said Rusli, Septri Widiono, dan Hana Indriana

\begin{abstract}
ABSTRAK
Perkembangan penduduk Pulau Jawa terus terjadi. Menurut hasil perhitungan indeks tekanan penduduk Pulau Jawa tahun 2006 diketahui sebesar 1,61 dan apabila Banten tidak dimasukkan ke dalam perhitungan tekanan penduduk menjadi 1,80. Estimasi indeks tekanan penduduk pada tahun 2010 menunjukkan adanya sedikit peningkatan menjadi 1,63 dan 1,83 jika tidak memasukkan Banten. Indikasi terjadinya over population Pulau Jawa didukung oleh hasil simulasi bahwa dengan jumlah penduduk saat ini, semestinya penduduk petani tidak lebih dari 24\%. Sedangkan dengan sistem pertanian yang diterapkan saat ini, jumlah lahan pertanian yang dibutuhkan untuk menghidupi seluruh penduduk Pulau Jawa adalah seluas 8.428 .980 ha setara sawah. Keadaan faktual menunjukkan jumlah pertanian sebanyak $41 \%$ dan luas lahan 4.863 .487 ha setara sawah. Hasil perhitungan tapak ekologi lahan pertanian Pulau Jawa menunjukkan bahwa tapak ekologi Pulau Jawa tahun 2006 bernilai 0,2339 Gha/orang atau 0,1064 ha/orang. Itu artinya setiap penduduk Pulau Jawa telah menggunakan lahan untuk konsumsi produk pertanian sebesar 0,1064 ha. Pada saat yang sama kemampuan lahan pertanian menyediakan produk pertanian sebesar 0,1111 Gha/orang atau 0,0551 ha/orang. Keadaan ini mengindikasikan bahwa kapasitas biologis lahan pertanian dalam menyediakan produk-produk pertanian yang dikonsumsi oleh penduduk sudah terlampaui (overshoot) sebesar 0,0536 Gha/orang atau 0,0513 ha/orang. Besarnya defisit lahan pertanian tersebar merata di setiap propinsi.
\end{abstract}

Keywords : tekanan penduduk, overshoot ekologi

\section{PENDAHULUAN}

\section{Latar Belakang}

Perkembangan penduduk senantiasa terjadi akibat faktor-faktor fertilitas, mortalitas, dan migrasi (Lucas dan Meyer, 1996). Faktor-faktor demografi tersebut sangat berkaitan dengan kondisi sosial, ekonomi, politik, dan budaya manusia. Teknologi yang dikembangkan pada dasarnya berguna untuk memudahkan aktivitas sosial. Dapat dipandang secara ekologis bahwa semua aktivitas itu merupakan kegiatan mengkonsumsi energi yang tersedia di alam dalam berbagai bentuk, baik yang langsung maupun tidak langsung. 
Secara keseluruhan, di alam ini akan terjadi pertukaran energi dari satu tempat ke tempat lainnya. Manusia yang hidup di suatu tempat, secara langsung mengkonsumsi energi pada tempatnya. Secara relatif, kumpulan manusia yang terlibat dalam pemanfaatan sumberdaya alam dan yang berinteraksi dengan sesamanya didukung oleh ekosistem dan jaringan ekosistem yang lebih besar (Marten, 2001).

Bagaimanapun juga, ekosistem dan lebih besar lagi jaringan antar ekosistem itu memiliki batas-batas dalam menopang semua aktivitas manusia tersebut. Salah satu pendekatan untuk mengkaji batas-batas keberlanjutan suatu ekosistem adalah ecological footprint (tapak ekologi). Ecological footprint mengukur permintaan penduduk atas alam dalam satuan metrik, yaitu area global biokapasitas. Dengan membandingkan ecological footprint dengan ketersediaan kapasitas biologis bumi, analisis ecological footprint (EFA) menyarankan apakah pemanfaatan lahan pertanian, hutan, peternakan, perikanan, ruang terbangun, lahan energi itu dapat dilanjutkan. Dalam laporan Footprint of Nations - Ecological Footprint Network (Footprint of Nations, 2005 Update - 2), disimpulkan bahwa penggunaan bumi kita sudah sampai pada batas keberlanjutan lingkungan (environmental sustainability). Alam telah digunakan melampaui kapasitasnya untuk memperbaharui dan meregenerasi. Tanda-tanda ini sudah bisa dirasakan seperti fenomena efek rumah kaca, deforestasi, degradasi lahan pertanian, dan meningkatnya kelangkaan sumberdaya alam.

Berkaitan dengan indikasi tersebut menarik untuk melakukan kajian daya dukung Pulau Jawa dengan menggunakan pendekatan tapak ekologi (ecological footprint). Menurut Global Footprint Network (GFN, 2006), Ecological Footprint merupakan suatu alat manajemen sumberdaya yang dapat mengukur seberapa banyak tanah dan air yang dibutuhkan oleh populasi manusia untuk menghasilkan sumberdaya yang dikonsumsinya serta untuk menyerap limbah sehubungan dengan penggunaan teknologi. Pada saat permintaan terhadap sumberdaya ekologis melampaui apa yang bisa disediakan oleh alam secara berkelanjutan, disebut sebagai kondisi ekologis yang terlampaui (ecological overshoot).

Indonesia belum pernah melakukan perhitungan tapak ekologi untuk negaranya. Salah satu informasi mengenai tapak ekologi Indonesia dapat diketahui dari publikasi Global Footprint Network (GFN) tahun 2005 dan 2006 (www.footprintnetwork.org). Hasil perhitungan GFN menunjukkan bahwa telah terjadi defisit ekologi sebesar 0,01 Gha/orang (data tahun 2002) kemudian menjadi 0,05 Gha/orang (data tahun 2003). Keadaan ini masih lebih baik jika dibandingkan dengan negara tetangga, Malaysia, dimana data tahun 2003 sudah mengalami defisit ekologi sebesar 1,5 Gha/orang. Tampaknya semakin maju suatu negara, besarnya defisit ekologi semakin besar. Sebagai ilustrasi misalnya, Jerman defisit 2,8 Gha/orang, Inggris 4,0 Gha/orang, dan Amerika Serikat 4,8 Gha/orang.

\section{Perumusan Masalah}

Pulau Jawa dengan berbagai karakteristik ekosistemnya, luasnya sebesar 121.071,25 $\mathrm{km}^{2}$ atau 121.071,25 ha ini dihuni oleh penduduk hampir 132.003.000 jiwa (BPS, 2007). Gejala menurunnya atau terlampauinya kapasitas biologis Pulau Jawa untuk menopang kehidupan sudah tampak pada berbagai bencana alam seperti banjir,

78 |Rusli, Said et.al. Tekanan Penduduk, Overshoot Ekologi Pulau Jawa, dan Masa Pemulihannya 
tanah longsor, kekeringan, berkurangnya cadangan air bawah tanah, kebakaran, luapan kandungan bumi, dan lain-lain serta fenomena permukiman kumuh. Jika melihat kondisi ini, dimana lebih dari separuh penduduk Indonesia menempati Pulau Jawa, cukup beralasan untuk mengaitkan gejala-gejala tersebut dengan kemungkinan telah terjadinya overshoot.

Dengan demikian, permasalahan utama penelitian ini adalah seberapa besar tekanan penduduk telah terjadi di Pulau Jawa? Selanjutnya, seberapa besar sebenarnya kemampuan daya dukung Pulau Jawa telah terlampaui (overshoot)? Lantas berapa lama dibutuhkan waktu untuk memulihkan kondisi ekologi Pulau Jawa?

\section{Tujuan Penelitian}

Penelitian ini dilatarbelakangi oleh fenomena overpopulation di Pulau Jawa. Fenomena ini menunjukkan menurunnya kapasitas biologis Pulau Jawa untuk menopang aktivitas penduduk. Penelitian bertujuan untuk mendapatkan gambaran mengenai tekanan penduduk, overshoot ekologi, dan masa pemulihan ekologi Pulau Jawa. Penelitian ini bertumpu pada data sekunder yang dikeluarkan Pemerintah secara resmi melalui berbagai instansinya. Hasil yang diharapkan adalah mengidentifikasi variabel-variabel yang menentukan kondisi ekologi dan manipulasinya untuk pemulihan ekologi.

\section{Kegunaan Penelitian}

Hasil penelitian ini diharapkan dapat menjadi suatu sintesa mengenai kependudukan dan daya dukung Pulau Jawa, sehingga dapat dimanfaatkan oleh instansi-instansi yang terkait dengan pembangunan, kependudukan, dan lingkungan hidup. Diharapkan hasil penelitian ini juga dapat memberikan gambaran mengenai tingkat tekanan penduduk agraris dan status lingkungan hidup di Pulau Jawa (khususnya). Di samping itu, penelitian ini diharapkan juga dapat dimanfaatkan oleh Badan Perencanaan Pembangunan Daerah melalui dinas-dinas terkait di masing-masing ibukota provinsi di Pulau Jawa agar dapat melakukan berbagai upaya guna mendorong, menjaga dan memulihkan daya dukung Pulau Jawa. Hasil penelitian ini diharapkan juga mendorong untuk dilakukan penelitian-penelitian serupa di daerahdaerah lain di luar Pulau Jawa.

\section{TINJAUAN PUSTAKA}

\section{Penduduk dan Daya Dukung Lingkungan}

Pentingnya perhatian terhadap daya dukung lingkungan terjadi ketika manusia menyadari bahwa daya dukung lingkungan terhadap kehidupan manusia dan makhluk-makhluk lain ada batas-batasnya, kendatipun tidak mudah ditentukan. Menjadi persoalan bagi manusia bagaimana agar lingkungan mampu secara berkelanjutan mendukung kehidupannya dengan tingkat kesejahteraan yang dipandang memadai.

Kehidupan manusia dengan berbagai macam kegiatannya menghasilkan limbah. Ketika jumlah penduduk masih sedikit terdapat keseimbangan antara jumlah limbah yang dibuang dengan kemampuan pemurnian dari lingkungan sehingga lingkungan tidak mengalami pencemaran atau hanya mengalami tingkat pencemaran yang rendah (Soemarwoto, 1995). Dengan makin meningkatnya jumlah penduduk di 
suatu wilayah maka jumlah limbah yang dihasilkan manusia melampaui kemampuan lingkungan untuk memurnikan diri, akibatnya, terjadilah pencemaran lingkungan.

Peringatan terhadap perkembangan penduduk yang dapat melampaui kemampuan sumberdaya yang mendukungnya sudah dimulai oleh Malthus pada akhir abad ke-18 (1798), meskipun Malthus hanya mempersoalkan hubungan antara perkembangan penduduk dan subsisten (pangan). Dalam perkembangannya, tampak ada kecenderungan yang dipentingkan adalah adanya keseimbangan antara sumberdayasumberdaya yang dimiliki dan jumlah penduduk yang menggunakan sunberdayasumberdaya itu (Huxley, 1955).

Konsep daya dukung (carrying capacity) dapat dipandang sebagai perkembangan lebih lanjut dari konsep kepadatan penduduk (population density). Kepadatan penduduk menunjukkan hubungan kuantitatif antara jumlah penduduk dan unit luas lahan. Untuk suatu daerah agraris, yang penting adalah kepadatan penduduk agraris yang menunjukkan jumlah penduduk yang tergantung hidupnya pada pertanian (jumlah petani dan keluarganya) per luas lahan pertanian.

Di samping kepadatan penduduk agraris, terdapat berbagai konsep kepadatan penduduk, antara lain kepadatan penduduk geografis dan kepadatan penduduk fisiologis. Konsep kepadatan penduduk yang paling umum adalah kepadatan penduduk geografis yang menunjukkan perbandingan antara jumlah penduduk dan luas lahan di suatu wilayah. Kepadatan penduduk fisiologis dihubungkan antara jumlah penduduk dan luas lahan pertanian di suatu wilayah (FAO, 1986).

Dengan demikian, konsep kepadatan penduduk dibangun atas dasar pengertian penduduk dan pengertian lahan. Pengertian penduduk mencakup keseluruhan penduduk (total penduduk), ataupun dibatasi pada penduduk yang hidupnya tergantung pada pertanian (petani dan keluarganya) di suatu wilayah. Lahan terdiri dari lahan yang dapat diusahakan (arable land atau cultivable land) dan lahan yang tidak dapat diusahakan (non-arable land). Pengertian lahan untuk perhitungan kepadatan penduduk geografis adalah keseluruhan lahan yang terdapat di suatu wilayah, baik arable land maupun non-arable land. Perhitungan kepadatankepadatan penduduk lainnya perlu didefinisikan secara jelas pengertian lahan yang dipakai.

Lahan pertanian dapat merupakan lahan yang potensial digunakan untuk usaha pertanian ataupun mungkin dibatasi pada lahan pertanian yang telah diusahakan (cultivated land) seperti luas sawah, ladang dan tegalan di suatu wilayah. Lahan pertanian mencakup pula lahan-lahan yang dengan satu atau lain cara memberikan manfaat (productive non-arable land) seperti wilayah hutan lindung yang dapat digunakan oleh penduduk untuk mengambil hasil hutan dan binatang buruan. Kepadatan penduduk dinyatakan dalam jumlah penduduk per unit luas lahan (jiwa per mil2, jiwa per km2, jiwa per hektar).

Konsep daya dukung (daya dukung lingkungan) lebih komprehensif dari pada konsep kepadatan penduduk. Pengertian daya dukung secara umum dapat dilihat pada pernyataan berikut: 
"Carrying capacity is the maximum population size that a species can maintain indefinitely in a given area-that is, without diminishing the capacity of the area to sustain the same population size in the future. Carrying capacity is thus a function of both the resource requirements of the organism and the size and richness of the area"(Ranganathan dan Daily, 2003)."

Konsep daya dukung menekankan kemampuan suatu daerah (wilayah) untuk mendukung jumlah maksimum populasi suatu spesies secara berkelanjutan pada suatu tingkat kebutuhan sumberdaya yang diperlukan. Dengan demikian, kemampuan ini sangat tergantung pada kekayaan sumberdaya yang dimiliki oleh suatu daerah dan tingkat kebutuhan sumberdaya oleh suatu organisme. Kemampuan daerah (wilayah) yang bersangkutan tidak pernah berkurang, atau secara terus menerus terpelihara.

Dihubungkan dengan jumlah manusia (penduduk) yang mampu didukung (ditampung) oleh lingkungan hidup di suatu wilayah secara berkelanjutan, konsep daya dukung menjadi lebih rumit karena peranan yang unik dari kebudayaan manusia. Terdapat tiga faktor kebudayaan yang saling terkait secara kritikal dengan daya dukung suatu wilayah (Ranganathan dan Daily, 2003), yaitu:

(1) Perbedaan-perbedaan individual dalam hal tipe dan kuantitas sumberdaya yang dikonsumsi.

(2) Perubahan yang cepat dalam hal pola konsumsi sumberdaya.

(3) Perubahan teknologi dan perubahan budaya lainnya.

Konsep daya dukung dipandang lebih bermakna untuk melihat jumlah manusia yang dapat ditampung di suatu wilayah (Rusli, 1996). Dalam hal ini, secara singkat, konsep daya dukung dapat dibatasi sebagai kemampuan untuk mendukung kehidupan manusia, yaitu untuk memenuhi kebutuhan-kebutuhan manusia. Daya dukung lahan terhadap jumlah penduduk hanya sebagian ditentukan oleh sumberdaya, iklim, dan kondisi fisik lainnya. Sedangkan faktor lain yang mempengaruhi adalah bagaimana cara-cara mengorganisir penduduk untuk menggunakan sumberdaya itu. Unsur teknologi memainkan peranan penting. Caracara penggunaan lahan yang lebih intensif mampu mendukung lebih banyak orang.

Daya dukung suatu wilayah terdiri dari daya dukung internal dan daya dukung eksternal (Zimmermann, 1964). Daya dukung internal adalah daya dukung yang berasal dari dalam wilayah, sedangkan daya dukung eksternal berasal dari luar wilayah yang bersangkutan. Dalam masyarakat modern, ketergantungan pada daya dukung eksternal tampak jelas. Penduduk dari suatu daerah dapat memperoleh penghidupannya di daerah lain dengan berbagai cara, seperti melalui perdagangan, investasi, dan memiliki lahan pertanian di luar daerah yang bersangkutan.

Dalam masyarakat modern, mengukur daya dukung suatu daerah terhadap penduduknya sukar dilakukan mengingat banyaknya faktor yang harus diperhitungkan. Hal ini berlainan dengan masyarakat primitif atau semi primitif 
tertutup, dimana penilaian daya dukung relatif mudah karena dapat didekati dengan hanya melihat daya dukung fisik (Rusli, 1996)

Daya dukung suatu wilayah bersifat dinamis. Daya dukung suatu wilayah, selain dipengaruhi oleh daya dukung eksternal, juga dipengaruhi oleh perubahanperubahan organisasi masyarakat dan teknologi dari tipe ekonomi pra agraris, agraris, hingga tipe ekonomi industri. Wiechel yang menggolong-golongkan penduduk dunia sampai pada kesimpulan tentang kepadatan penduduk bagi berbagai tipe ekonomi sebagaimana terlihat pada Tabel 1.

Tabel 1. Kepadatan Penduduk Menurut Tipe Ekonomi

\begin{tabular}{|l|c|}
\hline \multicolumn{1}{|c|}{ Tipe Ekonomi } & $\begin{array}{c}\text { Jumlah Orang per Mil } \\
\text { persegi*) }\end{array}$ \\
\hline 1. Berburu dan menagkap ikan & $1-8$ \\
2. Pastoral dan forestri & $8-26$ \\
3. Permulaan pertanian & $26-64$ \\
4. Pertanian & $64-92$ \\
5. Permulaan industri dan perdagangan & $192-256$ \\
6. Pertanian dan industri & $256-381$ \\
7. Industri lebih dominan & $381+$ \\
\hline
\end{tabular}

Sumber: Disebut oleh M.S. Jefferson "The Anthropology of Some Great Cities", American Geographical Society Bulletin XLI (1909), hal.543, dalam A.H.Hawley, Human Ecology (New York: The Ronald Press Company, 1950), hal. 151.

Undang-undang R.I No. 10 1992, membedakan daya dukung lingkungan menjadi daya dukung alam, daya tampung lingkungan binaan dan daya tampung lingkungan sosial sebagai berikut.

(1) Daya dukung alam adalah kemampuan lingkungan alam beserta segenap unsur dan sumbernya untuk menunjang perikehidupan manusia serta makhluk lain secara berkelanjutan.

(2) Daya tampung lingkungan binaan adalah kemampuan lingkungan hidup buatan manusia untuk memenuhi perikehidupan penduduk.

(3) Daya tampung lingkungan sosial adalah kemampuan manusia dan kelompok penduduk yang berbeda-beda untuk hidup bersama-sama sebagai satu masyarakat secara serasi, selaras, seimbang, rukun, tertib dan aman.

\section{Indeks Tekanan Penduduk}

Dalam memahami hubungan (interaksi) antara penduduk (manusia) dan lingkungan terdapat dua model dasar yang penting, yaitu model POET dan model IPAT. Model POET bersifat lebih umum dibandingkan dengan model IPAT. Kedua model tidak mempersoalkan tentang overpopulasi, tetapi model IPAT mempersoalkan bahwa penduduk merupakan salah satu faktor yang berpengaruh terhadap tekanan pada lingkungan.

Model POET terdiri dari empat variabel (unsur) yang terdiri dari Penduduk $(\mathrm{P}=$ Population $)$, Organisasi $(\mathrm{O}=$ Organization $)$, Lingkungan $(\mathrm{E}=$ Environment $)$, dan 
Tekonolgi ( $\mathrm{T}=$ Technology). Keempat variabel ini berhubungan timbal balik, saling tergantung (Duncan dalam Bharadway, 1992). Untuk dapat memahami hubungan penduduk dan lingkungannya, perlu dikaji bentuk organisasi sosial dan tipe teknologi yang digunakan (Orians dan Skumanich, 1997). Organisasi sosial dan tipe tekonologi dapat memediasi interaksi manusia dan lingkungannya. Variasi interaksi jumlah penduduk dengan lingkungannya tergantung pada teknologi yang digunakan penduduk yang bersangkutan dan sistem sosial (adat-istiadat) yang berlaku. Model POET berguna sebagai teori dasar, tetapi sedikit diaplikasikan terhadap isu-isu kebijakan.

Model IPAT banyak digunakan berkaitan dengan isu-isu lingkungan (dampak terhadap lingkungan) akibat perkembangan penduduk, meningkatnya kemakmuran penduduk sebagai hasil dari pertumbuhan ekonomi, dan perubahan teknologi yang digunakan. Pernyataan matematik hubungan variabel-variabel dalam model IPAT adalah sebagai berikut (Jones, 1993; Orians dan Skumanich, 1997):

$$
\mathrm{I}=\mathrm{P} \times \mathrm{A} \times \mathrm{T}
$$

dimana:

I = Dampak terhadap lingkungan

$\mathrm{P}=$ Tingkat kemakmuran individu, diukur dengan perkapita konsumsi barang dan jasa.

$\mathrm{T}=$ Teknologi diukur dengan energi yang digunakan per unit pendapatan (income) atau jumlah sumberdaya yang dikonsumsi dan polusi yang diciptakan selama produksi dan konsumsi per unit barang-barang dan jasa.

Tekanan penduduk (population pressure) merupakan gejala adanya kelebihan penduduk (overpopulasi) di suatu daerah, mengingat ketersediaan sumberdaya yang terdapat untuk kehidupan penduduk, sesuai dengan standar hidup yang diinginkan di daerah yang bersangkutan. Dikaitkan dengan daya dukung, tekanan penduduk terjadi ketika di daerah yang bersangkutan jumlah penduduknya telah melampaui daya dukung. Tekanan penduduk di suatu daerah atau suatu wilayah yang masih agraris dapat mengakibatkan terjadinya hal-hal berikut (lihat antara lain; Boeke, 1942; Geertz, 1956; Soemarwoto, 1985):

(1) Terjadinya kemerosotan tingkat hidup penduduk;

(2) Terjadinya ekspansi ke daerah lain untuk mendapatkan lahan usahatani dengan merambah hutan;

(3) Berkembangnya sistem sosial "shared poverty" (kemiskinan berbagi) yang berlandaskan pertanian;

(4) Gerak penduduk (permanen dan non-permanen) untuk mendapatkan peluang bekerja ataupun peluang berusaha di daerah lain.

Khusus daerah-daerah yang pada dasarnya masih bersifat agraris, telah dikembangkan oleh Soemarwoto (1985) suatu model kuantitatif Indeks Tekanan Penduduk. Beberapa faktor (variabel) dasar yang menentukan tekanan penduduk terhadap tanah pertanian di suatu daerah (wilayah) adalah: 
(1) Jumlah penduduk; dalam hal ini penduduk yang hidupnya tergantung pada pertanian (petani dan keluarganya);

(2) Luas tanah pertanian yang tersedia atau yang dapat diusahakan;

(3) Standar hidup yang diinginkan;

(4) Sistem pertanian yang dipraktekkan ataupun diterapkan;

(5) Pendapatan yang bersumber dari luar usahatani (luar pertanian).

Indeks Tekanan Penduduk untuk waktu tertentu dihitung sebagai berikut (Soemarwoto, 1985):

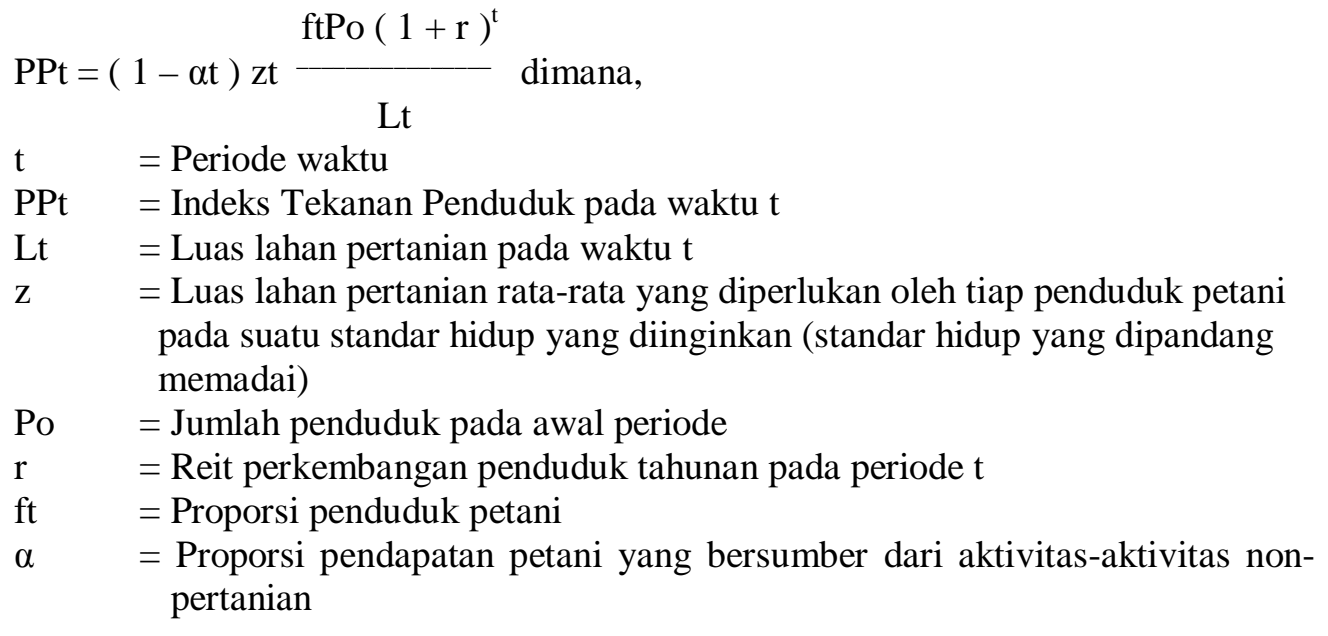

\section{Tapak Ekologi (Ecological Footprint)}

Konsep ecological footprint pertama kali dirintis oleh William Rees dan Mathis Wackernagel pada tahun 1996. Saat ini, pendekatan tersebut menjadi satu referensi yang paling penting untuk alat analisis keberlanjutan global (Rees dan Wackernagel, 1996). Dengan mengemukakan mengenai bagaimana mengurangi dampak penduduk terhadap alam, konsep ecological footprint menjadi isu dunia yang penting, setidaknya dalam dua cara pandang (McDonald dan Patterson 2003). Pertama, ecological footprint mengukur total biaya ekologis (dalam area lahan) dari suplai seluruh barang dan jasa kepada penduduk, hal ini menunjukkan bahwa penduduk tidak hanya secara langsung memerlukan lahan untuk produksi pertanian, jalan, bangunan dan lainnya, akan tetapi secara tidak langsung lahan pun turut mewujudkan barang dan jasa yang dikonsumsi penduduk. Dalam cara pandang seperti ini, ecological footprint dapat digunakan untuk membuat nyata biaya ekologis dari aktivitas penduduk.

Kedua, ecological footprint sebagai indikator keberlanjutan, yaitu carrying capacity. Carrying capacity dalam ekologi adalah jumlah populasi maksimum yang dapat didukung oleh area lahan tertentu. Konsep ini menunjuk untuk semua anggota ekosistem. Menjadi sangat menarik apabila populasi di sini adalah populasi manusia atau penduduk. Dengan menggunakan interpretasi kedua ini, Wackernagel dan Rees (1996) berpendapat bahwa ekologi hampir semua negara maju sudah tidak sustainable dimana ecological footprint melampaui kemampuan biokapasitas 
(overshoot). Pada tingkatan global, ecological footprint bagi seluruh umat manusia telah melampaui biokapasitas global sebesar 34 persen (Loh, 2000 dikutip oleh McDonald dan Patterson 2003).

Disinilah konsep ecological footprint mendapatkan titik temunya dengan konsep daya dukung lahan dan over population. Dimana, apabila area lahan tertentu sudah tidak mampu mendukung kehidupan sejumlah penduduk tertentu dengan tanda-tanda berkurangnya ketersediaan pangan dan kematian penduduk meningkat. Apabila daya dukung sudah semakin menurun maka kondisi ini disebut dengan over population (Rusli, 1995).

Penghitungan ecological footprint selalu didasarkan pada lima asumsi berikut ini (Venetoulis dan Talberth, 2005).

1. Sangat mungkin menelusuri jejak hampir seluruh sumberdaya yang dikonsumsi orang dan limbah yang dihasilkannya. Informasi ini dapat ditemukan di kantor statistik.

2. Hampir semua sumberdaya dan aliran limbah dapat dikonversi menjadi area produktif biologis yang dibutuhkan untuk memelihara aliran tersebut.

3. Perbedaan area dapat diekspresikan dalam satu unit yang sama (hektar atau are) yang disebut dengan skala proporsional produktivitas biomassa. Dengan kata lain, setiap ukuran lahan dapat diterjemahkan menjadi area yang ekuivalen dari rata-rata lahan produktif dunia

4. Sesudah setiap ukuran lahan distandarisasi yang menunjukkan jumlah yang sama dari produktivitas biomassa, maka dapat ditambahkan pada jumlah permintaan yang ditunjukkan manusia.

5. Area bagi total permintaan manusia ini dapat dibandingkan dengan jasa ekologis yang ditawarkan alam, saat itulah kita dapat menaksir area produktif di atas planet.

Terdapat beberapa isu yang harus diperhatikan dalam menghitung besarnya ecological footprint suatu wilayah. Dalam ISA Research Paper 01-03, Lenzen dan Murray (2003) menguraikan beberapa isu sebagai berikut. Pertama, penghitungan harus memasukkan semua area lahan. Lahan di sini mencakup baik lahan yang produktif maupun tidak produktif seperti gurun dan es. Jadi dalam pendekatan ini umpamanya lahan pertanian, mencakup lahan yang dapat diusahakan (arable land) dan lahan yang diusahakan (cultivated land).

Kedua, penghitungan memperhatikan inderect requirement dengan menggunakan analisis input-output. Dengan cara ini hubungan interdependensi antar sektor mulai dari rumah tangga, industri dan seterusnya dapat diuraikan secara lebih jelas. Prinsipnya, setiap kategori konsumsi memerlukan input yang bermula dari area lahan tertentu. Setiap aktivitas penduduk selalu memerlukan input dan menghasilkan output. Lahan diperlukan oleh setiap penduduk, disebut dengan direct land requirement. Sedangkan keperluan lainnya disebut dengan indirect land requirement. Penyedia barang dan jasa bagi penduduk dalam rantai interdependensi dan lahan yang dibutuhkannya dinamakan first-order requirements. Demikian 
seterusnya untuk penyedia tingkat kedua, ketiga dan seterusnya. Jumlah keseluruhan direct dan indirect requirements disebut dengan total requirements.

Ketiga, menggunakan area lahan aktual dan pentingnya gangguan terhadap lahan untuk mengatasi perbedaan kemampuan setiap lahan pada wilayah yang berbeda untuk pendukung penduduknya. Pendekatan ini merupakan koreksi yang dilakukan oleh Lenzen dan Murray atas konsep awal ecological footprint, dimana ia berpendapat bahwa katagori area hutan, padang gembalaan, dan lahan pertanian secara langsung karena katagori tersebut tidak menunjukkan lahan real. Kategori tersebut hanya hipotetis akibat tidak seragamnya kondisi lahan antar berbagai negara. Karenanya setiap jenis lahan harus dikonversikan ke dalam produktivitas rata-rata dunia dengan mempertimbangkan faktor gangguan terhadap lahan pada setiap negara. Setiap katagori lahan memiliki nilai ekuivalen dan yield factor. Dengan mempertimbangkan faktor gangguan, Lenzen dan Murray telah menetapkan suatu besaran antara 0 (tidak terganggu) sampai dengan 1 (terganggu sempurna), sebagai berikut (Tabel 2).

Tabel 2. Besaran Faktor Pengganggu Lahan

\begin{tabular}{lcc}
\hline & Land Use Type & Land Condition \\
\hline $\begin{array}{l}\text { CONSUMED } \\
\text { Built }\end{array}$ & 1.0 \\
\hline
\end{tabular}

DEGRADED

Degraded pasture or crop land

Mined land

REPLACED

Cleared pasture and crop land $\quad 0.6$

Non-native plantations

SIGNIFICANTLY DISTURBED

Thinned pasture

Urban parks and gardens

0.4

Native plantations

PARTIALLY DISTURBED

Partially disturbed grazing land

0.2

SLIGHTLY DISTURBED

Reserves and unused Crown land

Slightly disturbed grazing land

Sumber: Lenzen dan Murray. 2003). The Ecological Footprint-Issues and Trends. ISA Research Paper.

Keempat, memperhatikan isu emisi lahan terkait dengan perubahan iklim. Setiap perhitungan ecological footprint juga harus memperhatikan emisi CO2 yang dikeluarkan karena penggunaan bahan bakar minyak (energi) maupun yang lainnya seperti penebangan hutan, pembersihan lahan, fermentasi produk peternakan, proses industri, sampah, pertambangan dan sebagainya.

Dengan memperhatikan beberapa isu diatas, Global Footprint Network (GFN) yang merupakan kolaborasi 70 organisasi di dunia menyusun National Footprint Accounts (Wackernagel et al 2005). Saat ini metode yang dikembangkan oleh GFN menjadi 
standar bagi organisasi-organisasi di dunia ketika menyusun ecological footprint, termasuk Living Planet Report yang dikeluarkan oleh WWF (Kitzes et al 2007). Metode dasar penghitungan ecological footprint dilakukan dengan berpedoman pada katagori lahan teoretis ditambah dengan memasukkan keempat isu sebagaimana dikemukakan di atas. Dalam metode ini, pertama sekali dilakukan dengan cara mengindentifikasi semua item konsumsi populasi baik barang maupun jasa. Selanjutnya dilakukan perhitungan ecological footprint untuk masing-masing komponen itu.

Sampai saat ini, GFN telah mempublikasi dua kali National Footprint Accounts, yaitu tahun 2005 (data tahun 2002) dan tahun 2006 (data tahun 2003). Publikasi tahun 2006 merupakan hasil revisi terhadap publikasi sebelumnya dengan melengkapi berbagai kekurangan, terutama komponen lahan energi. Edisi terbaru GFN juga sudah menyertakan format perhitungan yang dapat diakses oleh siapa saja melalui situsnya (http://www.footprintnetwork.org) untuk dipergunakan baik kepentingan ekademis maupun komersial. Edisi terbarunya itu dinamakan Ecological Footprint and Biocapacity 2006 Edition.

Dengan pendekatan ini, perhitungan kualitas wilayah dikonversikan sebagai luasan area bioproduktif standar. Area ini mencakup lahan pertanian, padang rumput, perairan, hutan, dan lahan terbangun. Area bioproduktif ini disebut dengan Global Hektar (Gha). Setiap global hektar mewakili sejumlah area bioproduktif yang sama. Setiap golongan area memiliki faktor ekuivalen sendiri berdasarkan area produktif standar, yaitu rata-rata produktivitas dari 11,2 milyar hektar bioproduktif di bumi. Wackernagel et. al (2005) telah menghitung untuk setiap golongan area ini faktor ekuivalennya (Tabel 3).

Tabel 3. Faktor Equivalen Masing-Masing Area Biopoduktif

\begin{tabular}{llc}
\hline No & \multicolumn{1}{c}{ Area Bioproduktif } & $\begin{array}{c}\text { Faktor Equivalen } \\
\text { (Gha/Ha) }\end{array}$ \\
\hline 1. & Lahan Pertanian & 2,1 \\
& $-\quad$ Lahan primer & 2,2 \\
& $\quad-\quad$ Lahan marginal & 1,8 \\
2. & Lahan Gembalaan/Padang Rumput & 0,5 \\
3. & Hutan & 1,4 \\
4. & Perairan & 0,4 \\
5. & Lahan Terbangun & 2,2 \\
6. & Lahan Hydropower & 1,0 \\
7. & Bahan Bakar Fosil (Hutan) & 1,4 \\
\hline
\end{tabular}

Sumber : Wackernagel et. al (2005). National Footprint and Biocapacity Account 2005: The Underlying Calculation Method. Global Footprint Network.

Keterangan: (a) Angka di atas adalah pembulatan hingga satu desimal terdekat.

(b) Lahan terbangun diasumsikan bahwa sebagian besar bentuk penutupan bangunan menempati lahan pertanian primer sehingga nilai faktor equivalennya juga disamakan, yaitu 2,2. 
Area bioproduktif adalah katagori lahan teoretis dimana produktivitas biologis yang dikandunginya menyediakan kemampuan untuk menopang kehidupan manusia. Nilai kemampuan ini dinamakan biokapasitas. Jadi secara teoretis area bioproduktif memiliki biokapasitas yang berbeda-beda menurut wujudnya dan luasannya. Hal ini diindikasikan oleh besaran faktor equivalen, jadi biokapasitas adalah apa yang ditawarkan oleh permukaan bumi.

Pada sisi lain, ecological footprint adalah katagori teoretis terhadap penggunaan seluruh area bioproduktif dalam rangka memenuhi kebutuhan hidup manusia. Ecological footprint menghitung semua aktivitas manusia tersebut baik yang manghasilkan barang produktif maupun limbah. Jika dipadankan dengan sektorsektor ekonomi ecological footprint adalah kegiatan manusia di bidang pertanian, industri, perdagangan, jasa, dan energi. Jika dipadankan dengan ilmu lingkungan maka ecological footprint adalah semua bentuk pemanfaatan materi, informasi, dan energi di alam. Oleh karena itu ecological footprint harus dapat dikonversikan pada nilai yang setara dengan area bioproduktif yang bersesuaian dengannya. Misalnya, konsumsi bahan pangan merupakan penggunaan lahan pertanian. Dengan demikian, ecological footprint diekspresikan dalam satuan yang sama dengan biokapasitas, yaitu global hektar (Gha). Atas dasar itu pula Ecological footprint merupakan apa yang diminta oleh manusia untuk mendukung kehidupannya. Hasil dari permintaan itu adalah penggunaan barang, jasa, dan limbah yang terbuang di alam. Atas dasar itu pula, untuk selanjutnya dalam penelitian ini, istilah ecological footprint diterjemahkan menjadi tapak ekologi.

Tapak ekologi mengekspresikan apa yang ditinggalkan manusia di alam dalam wujud barang, jasa, dan limbah. Jumlah Gha dari keseluruhan aktivitas manusia dibandingkan dengan Gha biokapasitas yang tersedia di alam ini merupakan gambaran kualitas ekologi dimana manusia tersebut hidup. Apabila tapak ekologi lebih besar dibandingkan biokapasitas maka terjadi overshoot yang artinya daya dukung lingkungan telah terlampaui. Dalam kondisi ini terjadi defisit ekologi (ecological deficit) atau berstatus tidak sustainable. Sebaliknya jika tapak ekologi lebih kecil, maka terdapat sejumlah biokapasitas di alam yang tercadangkan untuk menopang kehidupan yang akan datang (ecological debt) atau berstatus sustainable.

Tampak bahwa negara atau wilayah yang mengalami ecological deficit menggunakan biokapasitas dari negara atau wilayah lain.

Tiga pengertian penting dalam penghitungan tapak ekologi dan biokapasitas perlu dikemukakan di sini, yaitu:

1. Global hektar (Gha) adalah area produktif terboboti (tanah dan air) yang digunakan sebagai satuan biokapasitas dan tapak ekologi. Satuan global hektar disini menunjukkan produktivitas area bioproduktif menurut jenis (seperti: lahan pertanian, padang rumput, hutan, perairan) pada tahun tertentu. Satu global hektar didefinisikan sebagai satu hektar lahan (tanah dan air) pada tahun tertentu setara dengan produktivitas rata-rata dunia seluas 11,2 milyar ha. Karena produktivitas lahan setiap tahun dapat berubah maka satu global hektar pada tahun tertentu bisa berbeda pada tahun yang lain, tidak termasuk ke alam area produktif seperti padang pasir, gunung es, dan lautan terbuka. 
2. Faktor equivalen (equivalent factor-Gha/ha) adalah faktor kunci untuk mengkonversi produktivitas satu hektar lahan-lahan tertentu ke dalam produktivitas rata-rata dunia, yakni dalam satuan global hektar (Gha). Nilai faktor equivalen ini menunjukkan tingkat produktivitas dari katagori lahan yang bersangkutan. Standar penentuannya adalah, jika katagori lahan tersebut lebih tinggi dibandingkan produktivitas semua area bioproduktif (tanah dan air) di permukaan bumi, maka faktor equivalennya bernilai lebih dari 1 (satu). Contohnya lahan pertanian 2,2 Gha/ha artinya 1 hektar lahan pertanian di dunia memiliki produktivitas 2,2 kali lebih tinggi dari rata-rata produktivitas 1 hektar seluruh tanah dan air yang ada di permukaan bumi.

3. Faktor hasil (yield factor -tidak bersatuan) adalah suatu besaran yang menunjukkan produktivitas lahan tertentu pada satu negara atau wilayah dibandingkan produktivitas dunia untuk katagori lahan tersebut. Faktor hasil mengkonversi satu hektar kategori lahan tertentu disuatu negara atau wilayah menjadi satu hektar rata-rata dunia untuk katagori lahan itu. Faktor hasil sama dengan satu jika produktivitas lahan di suatu negara atau wilayah sama dengan produktivitas rata-rata dunia untuk lahan itu. Faktor hasil dihitung untuk setiap jenis lahan pada tahun tertentu.

Dengan mengoperasikan balik faktor equvialen dan faktor hasil, besaran tapak ekologi dalam Gha dapat dinyatakan juga ke dalam hektar (ha) sehingga lebih menunjukkan luas lahan yang mudah diamati. Tapak ekologi baik dalam Gha maupun ha dapat dinyatakan dalam total penduduk yang hidup pada satu negara atau wilayah, dapat juga dinyatakan dalam satuan per kapita. Tapak ekologi per kapita menunjukkan jumlah lahan teoretis yang telah digunakan setiap orang di suatu negara atau wilayah. Oleh karena itu, dengan memperkirakan tingkat perkembangan penduduk suatu negara atau wilayah, tapak ekologi pada tahun-tahun berikutnya dapat juga dihitung.

\section{Tapak Ekologi Pulau Jawa}

Seperti disinggung pada bagian pendahuluan, Indonesia belum pernah melakukan perhitungan tapak ekologi untuk negaranya. Sebagai informasi, tapak ekologi Indonesia menurut perhitungan GFN, pada tahun 2002 adalah sebesar 1,0 Gha/orang kemudian menjadi 1,1 Gha/orang pada tahun 2003. Untuk level yang lebih rendah, pada tahun 2007, Kementerian Koordinator Bidang Perekonomian telah melakukan upaya penilaian terhadap daya dukung lingkungan Pulau Jawa yang salah satunya menggunakan pendekatan tapak ekologi.

Dasar perhitungan tapak ekologi Pulau Jawa yang digunakan oleh Kementerian Koordinator Bidang Perekonomian adalah kebutuhan lahan ideal per orang menurut standar dunia yang dikembangkan oleh Reese dan standar Indonesia yang dikembangkannya sendiri. Menurut standar dunia, kebutuhan lahan per orang untuk menopang seluruh aktivitas hidupnya adalah 4,18 ha/orang (Tabel 4). 
Tabel 4. Kebutuhan Lahan Per Orang Per Tahun Berdasarkan Kriteria Dunia

\begin{tabular}{clc}
\hline No. & \multicolumn{1}{c}{ Kebutuhan Lahan } & Jumlah (ha/orang) \\
\hline 1. & Untuk lahan energi & 2,34 \\
2. & Lahan terdegradasi & 0,20 \\
3. & Kebun & 0,02 \\
4. & Lahan pertanian & 0,66 \\
5. & Lahan peternakan & 0,46 \\
6. & Hutan & 0,50 \\
\hline & Total Kebutuhan Lahan & 4,18 \\
\hline
\end{tabular}

Sumber: Laporan Final Kajian Daya Dukung Lingkungan Pulau Jawa. Jakarta, PT Lemtek Konsultan Indonesia. 2007. hal. 16.

Sedangkan standar yang telah disesuaikan dengan kebutuhan rata-rata orang Indonesia, telah ditetapkan sebagai berikut (Tabel 5).

Tabel 5. Kebutuhan Lahan Per Orang Per Tahun Berdasarkan Kriteria Indonesia

\begin{tabular}{clcc}
\hline No & \multicolumn{1}{c}{ Kebutuhan Lahan } & Jumlah (ha/orang) & Persentase \\
\hline 1. & Lahan energi & 0,201 & 25,70 \\
2. & Lahan terdegradasi & 0,26 & 33,30 \\
3. & Kebun & 0,026 & 3,33 \\
4. & Lahan pertanian & 0,013 & 1,66 \\
5. & Lahan peternakan & 0,072 & 9,21 \\
6. & Hutan & 0,21 & 26,90 \\
\hline & Total Kebutuhan Lahan & 0,78 & 100 \\
\hline
\end{tabular}

Sumber: Laporan Final Kajian Daya Dukung Lingkungan Pulau Jawa. Jakarta, PT Lemtek Konsultan Indonesia. 2007. hal. 20.

Hasilnya, diperoleh bahwa dengan menggunakan data tahun 1996, telah terjadi defisit ekologi sebesar 462.832.500 ha (standar dunia) dan 75.606.500 ha (standar Indonesia) pada saat jumlah penduduk Pulau Jawa mencapai 113,89 juta jiwa. Perlu digarisbawahi dalam perhitungan itu adalah metodenya. Metode perhitungan yang digunakan adalah pendekatan kebutuhan lahan ideal sehingga dengan begitu total tapak ekologi penduduk Pulau Jawa tidak lain adalah kebutuhan lahan semua penduduk itu sendiri. Dengan kata lain, angka yang diperoleh adalah jumlah lahan ideal, bukan lahan yang telah terpakai secara faktual. Meskipun kebutuhan itu sendiri diperoleh dengan pijakan yang cukup beralasan, yakni mentransformasi kebutuhan hidup menjadi kebutuhan pangan dan serat. Adapun jenis kebutuhan yang diperhitungkan adalah kebutuhan pangan, perumahan, transportasi, energi, dan kebutuhan untuk daur ulang. Rincian asumsi untuk menetapkan kebutuhan lahan per orang adalah: 
1. Kebutuhan pangan adalah berdasarkan 4 sehat 5 sempurna.

2. Kebutuhan papan digunakan standard $\mathrm{T} 76$ perumahan Departemen PU: $90 \mathrm{~m}^{2}$ untuk keluarga terdiri dari 3 orang atau $20-30 \mathrm{~m}^{2}$ per orang.

3. Kebutuhan transportasi setara $120 \mathrm{~kg}$ beras/tahun.

4. Kebutuhan energi setara $120 \mathrm{~kg}$ beras/tahun.

5. Kebutuhan untuk daur ulang (air, $\mathrm{CO}_{2}$, limbah/sampah lainnya) setara dengan $120 \mathrm{~L}$ air/hari untuk kemampuan hutan mendaurkan air $0.3 \mathrm{~L}$ untuk tiap 1 liter dengan tinggi curah hujan rata-rata $2000-2500 \mathrm{~mm}$, dan $56 \mathrm{~kg} \mathrm{CO}_{2}$ per hektar hutan serta keanekaragaman hayati.

\section{METODE PENELITIAN}

\section{Sumber Data}

Penelitian ini menggunakan data-data keluaran Badan Pusat Statistik (BPS). Adapun jenis dokumen yang digunakan adalah: Statistik Indonesia 2007, Propinsi Dalam Angka 2002/2003 (setiap propinsi), Propinsi Dalam Angka 2005/2006 (setiap propinsi), Sensus Penduduk 2000, Sensus Pertanian 1993 (setiap propinsi), Sensus Pertanian 2003 (setiap propinsi), Survei Angkatan Kerja 2007, serta Konsumsi dan Pengeluaran Agustus 2007.

\section{Indeks Tekanan Penduduk}

Perhitungan indeks tekanan penduduk menggunakan rumus Otto Soemarwoto sebagaimana telah dikemukakan pada bab sebelumnya, yaitu :

$$
\mathrm{PP}_{\mathrm{t}}=\left(1-\alpha_{\mathrm{t}}\right) \mathrm{Z}_{\mathrm{t}}-\mathrm{F}_{\mathrm{t}} \mathrm{P}_{0}(1+\mathrm{r})^{\mathrm{t}}
$$

Keterangan:

$\mathrm{PP}_{\mathrm{t}} \quad=$ Indeks tekanan penduduk pada tahun $\mathrm{t}$

$\mathrm{t} \quad=$ Periode waktu

$\mathrm{L}_{\mathrm{t}} \quad=$ Luas lahan pertanian pada tahun $\mathrm{t}$

$\mathrm{Z}_{\mathrm{t}} \quad=$ Luas lahan pertanian rata-rata yang dibutuhkan oleh setiap penduduk petani pada standar hidup layak yang dinginkan

$\mathrm{P}_{0} \quad=$ Jumlah penduduk pada tahun awal

$\mathrm{r} \quad=$ Reit perkembangan penduduk tahunan pada periode $\mathrm{t}$

$\mathrm{F}_{\mathrm{t}} \quad=$ Proporsi penduduk petani

$\alpha_{\mathrm{t}} \quad=$ Proporsi pendapatan petani dari luar pertanian

Indeks tekanan penduduk dihitung pada setiap propinsi dan Pulau Jawa sebagai satu kesatuan. Perlu ditekankan di sini bahwa yang dimaksud Pulau Jawa adalah penjumlahan semua kesatuan wilayah administratif enam (6) propinsi di Pulau Jawa, yaitu DKI Jakarta, Jawa Barat, Jawa Tengah, DI Yogyakarta, Jawa Timur, dan Banten. Jadi sudah termasuk di dalamnya pulau-pulau kecil di wilayah administratif propinsi yang bersangkutan, seperti Madura, Kepulauan Seribu, Nusakambangan dan lainnya. 
Indeks tekanan penduduk yang dihitung adalah tahun 2006 dan 2010. Dipilih tahun 2005 sebagai tahun dasar untuk menentukan perkiraan jumlah penduduk pada tahun tersebut. Adapun data-data lain yang diperlukan selain produktivitas sawah (2006, 2010) dan luas lahan pertanian (2006), digunakan teknik ekstrapolasi linear dengan mengambil dua titik (tahun) sebagai dasar ekstrapolasi. Kemudian ditetapkan proporsi pendapatan luar pertanian sebesar 0,5 dengan pertimbangan bahwa untuk dapat dikatagorikan sebagai rumah tangga pertanian maka minimal pendapatan rumah tangga $50 \%$ berasal dari sektor pertanian; standar hidup layak yang diinginkan digunakan garis kemiskinan Bank Dunia yakni sebesar US \$ 2,00 (Rp 18.500,00) per kapita sehari; konversi padi menjadi beras sebesar 0,6; dan perbandingan produktivitas sawah, ladang/tegalan, perkebunan adalah 10:5:6.

Terakhir, dilakukan simulasi pada masing-masing tahun 2006 dan 2010 jika indeks tekanan penduduk sama dengan satu (1), yaitu simulasi I untuk mendapatkan proporsi penduduk petani, dan simulasi II untuk mendapatkan luas lahan pertanian. Tujuan dari dilakukannya dua kali simulasi ini adalah untuk memperoleh analisis yang lebih mendalam terkait dengan daya dukung sektor pertanian di Pulau Jawa, yakni agar tidak terjadi tekanan penduduk maka semestinya berapa penduduk petani yang dapat ditampung pada sektor pertanian serta berapa luas lahan yang dibutuhkan.

\section{Tapak Ekologi dan Biokapasitas}

Perhitungan tapak ekologi dan biokapasitas Pulau Jawa dalam penelitian ini menggunakan metode komponen-campuran yang dikembangkan oleh Global Footprint Network (Wackernagel, 2005).

Prinsip penghitungan tapak ekologi dan biokapasitas GFN adalah seperti terlihat pada Gambar 1.

Besarnya nilai faktor equivalen adalah seperti yang telah dipaparkan pada Tabel 3, sedangkan nilai-nilai global yield masing-masing katagori produk sangat bervariasi, sesuai yang ditetapkan oleh GFN dalam menghitung tapak ekologi dunia pada tahun 2006 (Ecological Footprint and Biocapacity 2006 Edition). Adapun faktor hasil (yield factor) untuk masing-masing katagori lahan ditetapkan angka 1.

\section{Masa Pemulihan Ekologi}

Pendekatan utama yang dipergunakan untuk menetapkan masa pemulihan kondisi ekologi dalam penelitian ini adalah dengan membandingkan kesetimbangan dua sisi sebagaimana digunakan dalam perhitungan tapak ekologi. Dua sisi itu adalah laju konsumsi dan laju rehabilitasi lahan. Oleh karena itu teknik utamanya melakukan estimasi pengeluaran konsumsi penduduk untuk mendapatkan besaran tapak ekologi dan membuat asumsi rasional langkah-langkah rehabilitasi lahan dan untuk mendapatkan angka peningkatan biokapasitas. 


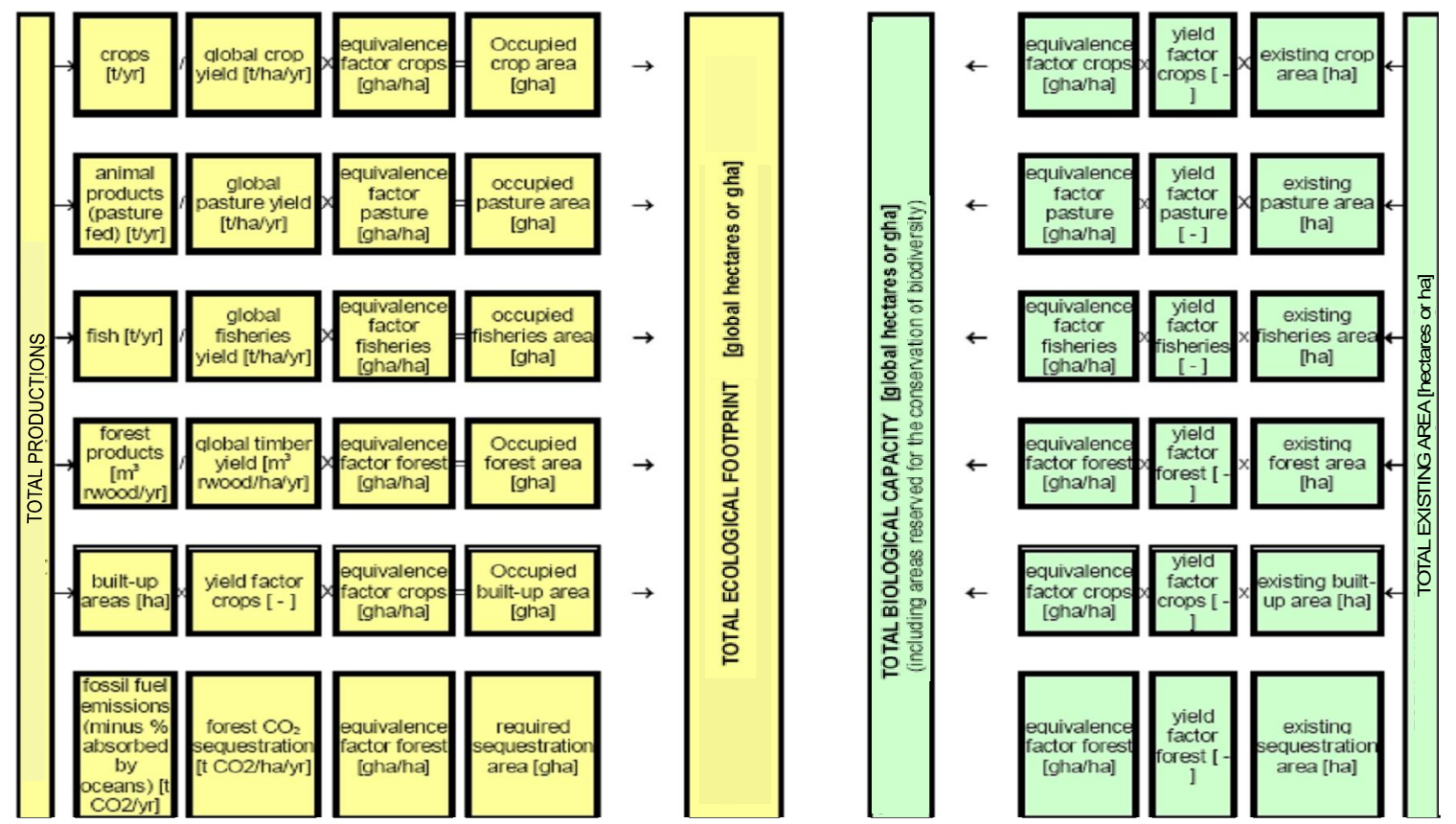

Gambar 1. Kerangka perhitungan ecological footprint dan biokapasitas Pulau Jawa

\section{HASIL DAN PEMBAHASAN}

\section{Perkembangan Penduduk dan Penggunaan Lahan}

Penduduk Pulau Jawa terus mengalami perkembangan jumlah sehingga mengkibatkan pertambahan kepadatan penduduk geografis pada setiap propinsi di Pulau Jawa. Untuk mengetahui tingkat perkembangan penduduk berikut disajikan data perkembangan penduduk Pulau Jawa menurut tahun sensus dan supas.

Tabel 6. Perkembangan Penduduk Pulau Jawa Tahun 1980, 1990, 2000, dan 2005

\begin{tabular}{lrrrrrrcc}
\hline \multirow{2}{*}{ Provinsi } & \multicolumn{4}{c}{ Jumlah Penduduk (Jiwa) } & \multicolumn{4}{c}{ r (\% per tahun) } \\
\cline { 2 - 10 } & \multicolumn{1}{c}{1980} & \multicolumn{1}{c}{1990} & 2000 & 2005 & $1990-$ & $\begin{array}{c}1990- \\
2000-\end{array}$ & $\begin{array}{c}2005- \\
2005\end{array}$ & 2010 \\
\hline DKI Jakarta & 6.503 .449 & 8.259 .266 & 8.384 .853 & 8.860 .381 & 2,41 & 0,16 & 1,11 & 0,76 \\
Jawa Barat & 27.453 .525 & 35.384 .352 & 43.552 .923 & 38.965 .440 & 2,57 & 2,17 & 1,96 & 1,81 \\
Jawa Tengah & 25.372 .889 & 28.520 .643 & 30.856 .825 & 31.977 .968 & 1,18 & 0,82 & 0,72 & 0,59 \\
DIYogyakarta & 2.750 .813 & 2.913 .054 & 3.109 .142 & 3.343 .651 & 0,57 & 0,68 & 1,46 & 1,71 \\
Jawa Timur & 29.188 .852 & 32.503 .991 & 34.525 .588 & 36.294 .280 & 1,08 & 0,63 & 1,00 & 0,98 \\
Banten & 4.015 .837 & 5.967 .907 & 8.096 .809 & 9.028 .816 & 4,04 & 3,21 & 3,48 & 3,32 \\
\hline Pulau Jawa & 95.285 .365 & 113.549 .213 & 128.526 .140 & 128.470 .536 & 1,66 & 1,17 & 1,30 & 1,20 \\
\hline
\end{tabular}

Sumber Data:

BPS, 2000. Penduduk Indonesia Hasil Sensus Penduduk 2000. Seri: RBL 1.1

BPS, 2006. Hasil Survey Penduduk Antar Sensus 2005. Seri: S1

BPS Prop. Banten, 2004. Banten Dalam Angka (khusus Banten r2000-2003 dan r2003-2010)

Keterangan: r 2005-2010 adalah hasil estimasi dengan teknik ekstrapolasi. 
Dalam periode tahun 1980-1990, penduduk Pulau Jawa masih memiliki perkembangan yang cukup tinggi, yakni mencapai 1,66 persen per tahun. Perkembangan penduduk menurun pada periode 1990-2000 hingga mendekati angka 1 persen per tahun. Pada periode itu tampaknya kebijakan pengendalian penduduk diperiode tahun sebelumnya mulai membuahkan hasil. Akan tetapi seiring dengan era otonomi daerah, dimana kebijakan kependudukan disesuaikan dengan kehendak daerah masing-masing, tampak bahwa penduduk Pulau Jawa mulai mengalami peningkatan kembali hingga 1,3 persen per tahun. Ekstrapolasi terhadap tingkat perkembangan penduduk Pulau Jawa menghasilkan sedikit penurunan, yakni 1,20 persen per tahun pada tahun 2005-2010.

Penggunaan lahan Pulau Jawa tahun 2006, dengan mengacu pada data Propinsi Dalam Angka disajikan pada Tabel 7.

Tabel 7. Penggunaan Lahan Pulau Jawa Tahun 2006 (Ha)

\begin{tabular}{|c|c|c|c|c|c|}
\hline Propinsi & $\begin{array}{c}\text { Lahan } \\
\text { Pertanian }\end{array}$ & $\begin{array}{l}\text { Padang } \\
\text { Rumput }\end{array}$ & Hutan & Perairan & $\begin{array}{c}\text { Lahan } \\
\text { Terbangun }\end{array}$ \\
\hline \multirow[t]{2}{*}{ DKI Jakarta } & $2.558,50$ & 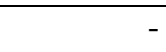 & 453,24 & 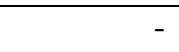 & $63.140,00$ \\
\hline & $(0,02)$ & $(0,00)$ & $(0,00)$ & $(0,00)$ & \\
\hline \multirow[t]{2}{*}{ Jawa Barat } & $2.029 .690,00$ & $43.062,00$ & $849.352,00$ & $71.975,00$ & $598.343,00$ \\
\hline & $(15,81)$ & $(0,34)$ & $(6,61)$ & $(0,56)$ & $(4,66)$ \\
\hline \multirow[t]{2}{*}{ Jawa Tengah } & $1.826 .778,00$ & $6.960,00$ & $651.137,00$ & $49.191,00$ & $720.346,00$ \\
\hline & $(14,23)$ & $(0,05)$ & $(5,07)$ & $(0,38)$ & $(5,61)$ \\
\hline \multirow[t]{2}{*}{ DI Yogyakarta } & $153.348,00$ & 535,00 & $52.634,00$ & 694,00 & $111.369,00$ \\
\hline & $(1$, & & $(0,41)$ & & $(0,87)$ \\
\hline \multirow[t]{2}{*}{ Jawa Timur } & $2.473 .380,00$ & $10.712,00$ & $1.217 .502,00$ & $69.965,00$ & $806.120,00$ \\
\hline & $(19,26)$ & $(0,08)$ & $(9,48)$ & & $(6,28)$ \\
\hline \multirow{2}{*}{ Banten } & $680.029,30$ & $36.641,00$ & $77.133,59$ & $7.389,74$ & $231.474,13$ \\
\hline & $(5,30)$ & $(0,29)$ & $(0,60)$ & $(0,06)$ & $(1,80)$ \\
\hline \multirow[t]{2}{*}{ Pulau Jawa } & $7.165 .783,80$ & $97.910,00$ & $2.848 .211,83$ & $199.214,74$ & $2.530 .792,13$ \\
\hline & $(55,80)$ & $(0,76)$ & $(22,18)$ & $(1,55)$ & $(19,71)$ \\
\hline
\end{tabular}

Keterangan: (lihat Lampiran 1)

1. Lahan pertanian mencakup sawah, ladang, tegalan, dan perkebunan.

2. Padang rumput mencakup padang rumput dan lahan sementara tidak diusahakan.

3. Hutan mencakup hutan rakyat/kayu-kayuan dan hutan negara.

4. Perairan mencakup kolam, tebat, empang, dan rawa-rawa.

5. Lahan terbangun mencakup pekarangan dan bangunan serta lahan kering lainnya.

6. Angka dalam kurung adalah persentase terhadap luas Pulau Jawa.

Sumber:

1. Propinsi Dalam Angka 2006/2007, BPS.

2. Sensus Pertanian 2003 Hasil Pendaftaran Rumah Tangga Propinsi Banten, BPS.

3. Sensus Pertanian 1993 Hasil Pendaftaran Rumah Tangga Propinsi Banten, BPS.

Lahan di Pulau Jawa sebagian besar merupakan lahan pertanian $(55,80 \%)$ dengan propinsi yang paling luas lahan pertaniannya Jawa Timur, kemudian disusul Jawa Barat $(15,81 \%)$ dan Jawa Tengah $(14,23 \%)$ (Tabel 7). Jika dicermati Tabel 7, ternyata lahan terbangun di Pulau Jawa sudah menduduki peringkat ketiga $(19,71 \%)$ setelah lahan pertanian dan hutan $(22,18 \%)$. Data citra satelit pada tahun 2005 (PT 
Lemtek Konsultan Indonesia 2007) menunjukkan bahwa sebagian besar komponen hutan yang menyumbang paling banyak adalah hutan negara yang berwujud hutan mangrove/hutan rawa, hutan tanaman, dan hutan sekunder sedangkan hutan alam hanya sedikit, yakni sekitar 2,8\% dari luas Pulau Jawa (Tabel 8).

Tabel 8. Hasil Penafsiran Citra Landsat terhadap Penutupan Hutan di Pulau Jawa, 2005

\begin{tabular}{|c|c|c|c|c|c|c|c|}
\hline \multirow[t]{2}{*}{ Propinsi } & Hutan $A$ & lam & $\begin{array}{c}\text { Mangr } \\
\text { ove \& } \\
\text { Hutan } \\
\text { Rawa }\end{array}$ & $\begin{array}{c}\text { Hutan } \\
\text { Lahan } \\
\text { Kering/ } \\
\text { Sekunde } \\
\text { r }\end{array}$ & $\begin{array}{c}\text { Hutan } \\
\text { Tanaman }\end{array}$ & \multicolumn{2}{|c|}{ Semua Hutan } \\
\hline & (ha) & $(\%)$ & (ha) & (ha) & (ha) & (ha) & $(\%)$ \\
\hline Banten & 16.541 & 1,8 & 96.308 & 96.567 & 57.243 & 266.659 & 29,4 \\
\hline DKI Jakarta & - & 0,0 & 3 & 949 & 104 & 1.055 & 1,6 \\
\hline Jawa Barat & 136.052 & 3,8 & 209.073 & 401.355 & 254.649 & 1.001 .128 & 27,7 \\
\hline Jawa Tengah & 15.250 & 0,5 & 54.176 & 163.157 & 185.757 & 418.340 & 13,1 \\
\hline DI Yogyakarta & 292 & 0,1 & 9 & 21.831 & 1.586 & 23.718 & 7,5 \\
\hline Jawa Timur & 179.803 & 3,9 & 22.657 & 384.295 & 70.220 & 656.976 & 14,4 \\
\hline \multirow{2}{*}{ P. Jawa } & 347.941 & 2,8 & 382.224 & 1.068 .153 & 569.559 & $2,367,876$ & \\
\hline & \multicolumn{2}{|l|}{2,8} & 3,0 & 8,5 & 4,5 & 18,7 & \\
\hline
\end{tabular}

Sumber: Laporan Final Kajian Daya Dukung Lingkungan Pulau Jawa. Jakarta, PT Lemtek Konsultan Indonesia. 2007. hal. 45.

\section{Angkatan Kerja dan Pengeluaran Penduduk}

Merujuk pada data BPS tahun 2007, penduduk Pulau Jawa 66,4 persen menjadi tenaga kerja di sektor non pertanian dan hanya 34,6 persen yang menjadi tenaga kerja di sektor pertanian. Namun jumlah penduduk Pulau Jawa yang bekerja di sektor pertanian mencapai sebaran jumlah terbesar dibandingkan dengan sektorsektor pekerjaan lainnya yakni sebesar 33,59 persen (Lampiran 2).

Kondisi ini menunjukkan bahwa bagi penduduk di Pulau Jawa, sektor pertanian masih menjadi lapangan kerja utama dibandingkan 8 lapangan kerja lainnya yakni pertambangan dan penggalian (0,67 persen), industri pengolahan 16,03 persen), listrik, gas, dan air (0,18 persen), perdagangan besar, eceran, rumah makan, dan hotel (23,35 persen), angkutan pergudangan dan komunikasi (6,38 persen), keuangan, asuransi, usaha persewaan bangunan, tanah dan jasa perusahaan $(1,66$ persen), dan jasa kemasyarakatan (12,32 persen). Demikian pula ditinjau dari proporsi jumlah penduduk di Pulau Jawa yang tersebar pada 9 lapangan kerja utama terhadap jumlah penduduk yang bekerja di Indonesia. Dari total jumlah penduduk yang bekerja pada lapangan kerja utama tersebut di Indonesia sebanyak 99,930,217 jiwa, tenaga kerja di sektor pertanian berada di Pulau Jawa adalah sebanyak 20.123.012 jiwa (20,14 persen). Jadi, baik di Pulau Jawa maupun di Indonesia secara keseluruhan, sampai saat ini penduduk masih menggantungkan hidupnya pada sektor pertanian.

Namun, merujuk pada data tahun 1971, persentase penduduk di Pulau Jawa yang bekerja di sektor pertanian adalah sekitar 62 persen, dalam kurun waktu 1971-2007 
proporsi tersebut semakin mengecil menjadi sebesar 33,59 persen. Sementara itu, sektor manufaktur (pertambangan dan penggalian, industri pengolahan, listrik, gas, air, dan bangunan) serta sektor jasa (angkutan pergudangan dan komunikasi, keuangan, asuransi, usaha persewaan bangunan, tanah dan jasa perusahaan, jasa kemasyarakatan) menunjukkan angka yang semakin meningkat. Dari tahun 1971 ke 2007 kenaikan jumlah tenaga kerja di sektor non-pertanian (manufaktur) terjadi dari 32 persen, menjadi 66,41 persen. Kondisi ini menunjukkan bahwa meskipun terjadi penurunan proporsi jumlah tenaga kerja di sektor pertanian, di sisi lain terjadi peningkatan proporsi jumlah tenaga kerja di sektor manufaktur dan sektor jasa.

Penurunan proporsi penduduk petani terhadap lahan semakin mengintensifkan bentuk-bentuk penggunaan lahan. Dengan semakin banyaknya tenaga kerja di sektor non pertanian, justru akan meningkatkan bentuk-bentuk aktivitas pemanfaatan lahan selain aktivitas budidaya tanaman dan infrastruktur pendukung, seperti perluasan area terbangun, pembangunan jalan dan peningkatan penggunaan energi. Di samping itu, juga akan terjadi upaya-upaya intensifikasi lahan yang dalam jangka waktu tertentu dapat menurunkan daya dukung lahan khususnya untuk menghasilkan produk pertanian dan menjaga kelangsungan ekosistem lahan itu sendiri. Lebih lanjut, kemampuan daya dukung lahan akan semakin berkurang untuk menopang jumlah dan aktivitas penduduk yang semakin meningkat untuk mengintensifkan lahan.

Adapun pengeluaran penduduk untuk konsumsi bahan makanan dan bukan makanan diasumsikan sebagai biaya yang dikeluarkan untuk mengkonsumsi berbagai produk baik pertanian, perikanan, kehutanan, perkebunan, penggunaan area terbangun dan pemanfaatan sumber-sumber energi ${ }^{1}$. Pada tahun 2007, di Pulau Jawa, pengeluaran rata-rata per kapita di Propinsi DKI Jakarta adalah tertinggi dibandingkan dengan pengeluaran rata-rata per kapita di propinsi-propinsi lainnya yakni pengeluaran ratarata untuk bahan makanan adalah sebesar Rp 272.821,00 dan untuk bukan makanan adalah Rp 500.586,00- (Lampiran 3). Kondisi ini terkait dengan kenyataan bahwa Propinsi DKI Jakarta sebagai pusat kegiatan perekonomian dan pemerintahan serta tempat mengalirnya barang dan jasa. Sebagian besar kebutuhan penduduk akan bahan makanan dan bukan makanan yang bersumber dari produk pertanian, perikanan, kehutanan dan perkebunan didatangkan dari luar propinsi DKI Jakarta. Hal ini menyebabkan biaya distribusi produk-produk tersebut lebih besar sehingga harga-harga barang tersebut menjadi relatif lebih mahal. Selain itu, DKI Jakarta menjadi daerah tujuan migrasi sehingga tekanan penduduk di propinsi ini sangat tinggi. Oleh karena itu, permintaan terhadap bahan makanan dan bukan makanan

\footnotetext{
${ }^{1}$ Pengeluaran rata-rata per kapita adalah biaya yang dikeluarkan untuk konsumsi semua anggota rumah tangga. Konsumsi rumah tangga dibedakan atas konsumsi makanan maupun bukan makanan tanpa memperhatikan asal barang dan terbatas pada pengeluaran untuk kebutuhan rumah tangga saja, tidak termasuk konsumsi/pengeluaran untuk keperluan usaha atau yang diberikan kepada pihak lain. Pengeluaran untuk konsumsi dihitung selama seminggu yang lalu, sedangkan untuk bukan makanan sebulan dan setahun yang lalu. Baik konsumsi makanan maupun bukan makanan selanjutnya dikonversikan ke dalam pengeluaran rata-rata sebulan. Angka-angka konsumsi/pengeluaran rata-rata per kapita yang disajikan dalam data BPS 2007 diperoleh dari bagi hasil jumlah konsumsi seluruh rumah tangga (baik mengkonsumsi makanan maupun tidak) terhadap jumlah penduduk.
} 
pun semakin besar yang berpengaruh pada semakin tingginya harga-harga bahan makanan dan bukan makanan.

Sejalan dengan permintaan penduduk yang semakin besar terhadap area pemukiman dan semakin banyaknya lahan-lahan yang dijadikan pusat-pusat perbelanjaan, perkantoran, serta jalan raya. Di tengah tekanan penduduk yang semakin besar seiring dengan semakin meningkat pula kebutuhan terhadap pemukiman, maka biaya yang harus dikeluarkan untuk memperoleh pemukiman semakin besar pula. Di samping itu, juga terjadi peningkatan kebutuhan terhadap penggunaan energi seperti bahan bakar minyak, listrik, dan gas.

Dari data SUSENAS tahun 2007, lebih lanjut diketahui bahwa pengeluaran rata-rata per kapita di Pulau Jawa mengalami peningkatan dari tahun ke tahun (Lampiran 4). Kondisi ini dapat dikaitkan dengan terjadinya tekanan penduduk di Pulau Jawa yang berarti terjadinya peningkatan atas permintaan terhadap bahan makanan dan bukan makanan, sehingga lebih lanjut berdampak pada kenaikan harga barang-barang tersebut. Oleh karena itu, biaya yang dikeluarkan untuk mengkonsumsi barang-barang tersebut juga akan semakin meningkat.

\section{Indeks Tekanan Penduduk}

Indeks tekanan penduduk Pulau Jawa menggambarkan tingkat daya dukung agraris Pulau Jawa terhadap penduduk yang ditopang oleh sektor pertanian. Hasil perhitungan menunjukkan bahwa pada tahun 2006 telah terjadi tekanan penduduk dengan indeks sebesar 1,61 (Tabel 9). Propinsi yang paling tinggi tekanan penduduknya adalah Jakarta $(9,67)$. Hanya Propinsi Banten yang belum mengalami tekanan penduduk $(0,93)$. Angka indeks di Banten mengindikasikan di Propinsi itu sudah hampir terjadi tekanan penduduk. Propinsi dengan tekanan penduduk tinggi setelah Jakarta ialah DI Yogyakarta $(2,24)$.

Tekanan penduduk sedikit mengalami peningkatan pada estimasi tahun 2010, yakni menjadi 1,63. Propinsi DKI Jakarta paling tinggi peningkatannya $(10,90)$, disusul kemudian oleh DI Yogyakarta $(2,43)$. Hanya Propinsi Banten yang mengalami penurunan indeks tekanan penduduk $(0,75)$. Penurunan ini lebih diakibatkan karena terjadi peningkatan luas lahan pertanian dari 457.978 menjadi 647.579 ha sawah (Lampiran 5).

Tabel 9. Indeks Tekanan Penduduk Pulau Jawa Tahun 2006 dan 2010

\begin{tabular}{lcc}
\hline \multicolumn{1}{c}{ Propinsi } & $\mathbf{2 0 0 6}$ & $\mathbf{2 0 1 0}$ \\
\hline - DKI Jakarta & 9,67 & 10,90 \\
- Jawa Barat & 1,27 & 1,30 \\
- Jawa Tengah & 1,93 & 2,01 \\
- DI Yogyakarta & 2,24 & 2,43 \\
- Jawa Timur & 1,69 & 1,78 \\
- Banten & 0,93 & 0,75 \\
\hline Pulau Jawa & 1,61 & 1,63 \\
Pulau Jawa (kecuali Banten) & 1,80 & 1,83 \\
\hline
\end{tabular}

Propinsi Banten dapat dikeluarkan dari perhitungan dengan berbagai pertimbangan seperti: secara faktual Banten adalah propinsi yang baru dimekarkan dari Jawa 
Barat, adanya data pencilan yaitu laju perkembangan penduduk (Tabel 6), dan adanya beberapa data penggunaan lahan yang tidak tersedia (Lampiran 1). Apabila hal ini dilakukan maka indeks tekanan penduduk Pulau Jawa menjadi lebih tinggi, yakni mencapai angka 1,80 pada tahun 2006 dan diperkirakan meningkat menjadi 1,83 pada tahun 2010 . Kesimpulan yang bisa diajukan di sini adalah, meskipun datadata yang dapat dianggap kurang valid karena berbagai sebab tetap diperhitungkan, daya dukung Pulau Jawa telah terlampaui merupakan suatu kesimpulan yang sahih.

Tekanan penduduk Pulau Jawa jika dikaitkan dengan tingkat perkembangan penduduk menunjukkan bahwa telah terjadi over population dengan reit perkembangan penduduk (r) 2005-2010 sebesar 1,2 persen per tahun. Jika dikaitkan dengan sistem pertanian, ini berarti bahwa produksi pertanian yang dihasilkan tidak mendatangkan pendapatan yang mencukupi untuk memenuhi kebutuhan penduduk agraris Pulau Jawa. Secara faktual, produksi pertanian yang dihasilkan dengan tingkat teknologi tertentu sangat ditentukan oleh luas lahan yang diusahakan petani. Dengan mengacu pada bentuk pertanian yang eksis di Jawa, produksi pertanian itu dapat dikonversi ke dalam satuan produksi pertanian sawah. Luas lahan pertanian faktual setelah dihitung menghasilkan angka 5.321.465 ha setara sawah, pada tahun 2006 (Lampiran 1). Diperkirakan akan sedikit meningkat menjadi 5.452.112 ha pada tahun 2010. Dalam perhitungan ini, digunakan asumsi produktivitas pertanian padi sawah berdasarkan produksi aktual tahun 2006 pada masing-masing propinsi berkisar antara 4,68 sampai dengan 5,74 ton/ha.

Indeks tekanan penduduk lebih dari satu seperti ini merupakan suatu justifikasi bahwa Pulau Jawa mengalami kelambatan pertumbuhan sektor pertanian bila dibandingkan dengan laju perkembangan penduduknya. Patut diakui bahwa pergeseran kesempatan kerja di Pulau Jawa memang sudah mengarah pada adanya lompatan dari sektor agraris ke industri dan jasa sebagaimana yang sudah dikemukakan pada bagian angkatan kerja. Pada satu sisi telah terjadi gejala transformasi, pada sisi lain pertumbuhan penduduk masih cukup tinggi. Pergeseranpergeseran tersebut mengarahkan pada pembahasan kontribusi sektor pertanian yang memang memiliki leveling off. Kenyataan demikian harus dipahami dari sisi bahwa perhitungan indeks tekanan penduduk di sini hanya memasukkan sektor pertanian sebagai satu-satunya sektor yang memberikan kontribusi paling besar dalam kehidupan. Dengan kata lain, Pulau Jawa masih dapat disebut sebagai daerah agraris apabila dilihat dari mata pencaharian penduduk yang masih tinggi di sektor ini meskipun dengan kecenderungan menurun, yakni dari 42\% tahun 1990 menjadi 40 persen tahun 2000 dan 36 persen tahun 2005. Adanya keterbatasan daya dukung sektor pertanian ini dikuatkan melalui hasil simulasi dengan cara mempertahankan indeks tekanan penduduk menjadi 1 (Tabel 10). 
Tabel 10. Hasil Simulasi I dan II jika Indeks Tekanan Penduduk Pulau Jawa sama dengan 1

\begin{tabular}{lcccr}
\hline \multirow{2}{*}{ Propinsi } & \multicolumn{2}{c}{$\begin{array}{c}\text { Proporsi Penduduk Petani } \\
\text { (SIMULASI I) }\end{array}$} & \multicolumn{2}{c}{$\begin{array}{c}\text { Luas Lahan Pertanian dalam } \\
\text { Hektar Sawah } \\
\text { (SIMULASI II) }\end{array}$} \\
\cline { 2 - 5 } & $\mathbf{2 0 0 6}$ & $\mathbf{2 0 1 0}$ & $\mathbf{2 0 0 6}$ & $\mathbf{2 0 1 0}$ \\
\hline - DKI Jakarta & 0,00 & 0,00 & 24.749 & 26.560 \\
- Jawa Barat & 0,22 & 0,20 & 1.915 .526 & 1.947 .921 \\
- Jawa Tengah & 0,26 & 0,25 & 2.737 .719 & 2.819 .813 \\
- DI. Yogyakarta & 0,19 & 0,18 & 236.122 & 249.601 \\
- Jawa Timur & 0,29 & 0,28 & 3.090 .736 & 3.208 .937 \\
- Banten & 0,28 & 0,35 & 424.129 & 483.320 \\
\hline Pulau Jawa & 0,24 & 0,23 & 8.428 .980 & 8.736 .153 \\
\hline
\end{tabular}

Hasil simulasi I menunjukkan bahwa sektor pertanian dengan tingkat teknologi yang selama ini diterapkan hanya mampu mendukung $24 \%$ penduduk Pulau Jawa tahun 2006 dan 23\% tahun 2010. Jika penduduk Pulau Jawa pada tahun 2006 berjumlah 130.012.182 orang, berarti sektor pertanian dapat menampung penduduk 31.118.264 orang. Dengan membandingkan data hasil ekstrapolasi, maka terdapat kelebihan penduduk yang bekerja di sektor pertanian sebanyak 6.406 .413 orang. Apabila dikaitkan dengan tekanan penduduk, maka kelebihan penduduk petani ini semestinya dapat ditampung pada sektor lain selain pertanian agar daya dukung Pulau Jawa tidak terlampaui. Adanya kelebihan penduduk petani mengindikasikan bahwa aplikasi teknologi pertanian dan lebih luas lagi sistem pertanian yang dikembangkan masih menjadi penopang sebagian besar penduduk Pulau Jawa sebagai sektor penyelamat susbsisten. Sektor pertanian terpaksa menampung jumlah penduduk yang semestinya ditampung pada sektor lain sehingga mengakibatkan kepemilikan lahan pertanian yang semakin sempit.

Apabila hendak dipaksakan menampung penduduk itu, maka sektor pertanian harus dikembangkan pada lahan yang lebih luas lagi. Hasil simulasi II menunjukkan setidaknya diperlukan lahan pertanian setara sawah seluas 8.428 .980 ha di tahun 2006 dan 8.763.153 ha di tahun 2010 (Tabel 10). Jika dibandingkan dengan luas lahan pertanian yang diusahakan petani maka terdapat backlog sebesar 3.107.515 ha pada tahun 2006 dan 3.284.041 ha pada tahun 2010 (Bandingkan dengan Lampiran $1)$.

Pertanyaannya adalah, apabila penduduk yang memang betul-betul memiliki keterampilan bertani sebanyak saat ini, masih mungkinkah menyediakan lahan pertanian sebanyak itu di Pulau Jawa? Suatu alternatif adalah melakukan reforma agraria yang mendukung perkembangan sektor pertanian rakyat dimana tanah-tanah terlantar didistribusikan kepada petani dan tanah yang secara fisis-biologis sesuai untuk lahan pertanian dicegah dari konversi menjadi areal non pertanian. Alternatif lain adalah lebih dikembangkan pekerjaan-pekerjaan di luar sektor pertanian bagi para petani. Transmigrasi menjadi pilihan lain yang kembali dapat ditawarkan. Tentunya di era otonomi daerah ini, pengertian transmigrasi harus dengan sungguhsungguh direformasi menjadi penciptaan daya tarik daerah lain di luar Jawa, terutama pengembangan sektor pertanian. Tawaran ini berimplikasi pada perlunya 
mendukung indutrialisasi pedesaan luar Jawa dengan cara menciptakan pusat-pusat pertumbuhan wilayah pada titik-titik yang sangat berpotensi memiliki banyak kaitan dengan sektor-sektor perdagangan, industri, dan jasa.

\section{Tapak Ekologi}

Untuk mendapatkan gambaran mengenai kualitas ekologi Pulau Jawa yang telah terlampaui kapasitas biologisnya secara kualitatif kita dapat menyebut beberapa contoh gejala bencana alam. Bencana alam di era sekarang tidak semata-mata dimengerti sebagai peristiwa alam yang tidak mampu dikendalikan bahkan tidak dapat dijelaskan asal-asul dan penyebabnya. Kekuatan ilmu pengetahuan dalam menjelaskan hubungan sebab akibat berbagai peristiwa alam antara lain menjadi pokok pembahasan ilmu-ilmu biologi, ekologi, dan lingkungan. Pendek kata di era kepemimpinan ilmu pengetahuan dewasa ini, berbagai bencana alam selalu diusahakan ada penjelasan kausalitasnya. Bencana alam yang sudah mendapatkan penjelasan ilmiah itu dinamakan bencana alam akibat perbuatan manusia, contohnya banjir, tanah longsor, kabut asap, pemanasan global, dan perubahan iklim/cuaca.

Gambaran kualitatif tersebut secara kuantitatif dapat dijelaskan ke dalam angkaangka besaran tapak ekologi penduduk yang tinggal di Pulau Jawa. Pulau Jawa sebagaimana diuraikan pada bagian sebelumnya, penggunaan lahan masih didominasi oleh lahan pertanian. Wilayah hijau alam dengan vegetasi hutan sudah semakin menipis akibat meluasnya lahan terbangun baik untuk perumahan dan bangunan perkantoran, sarana umum, maupun industri. Tingkat konsumsi penduduk Pulau Jawa juga digambarkan cukup tinggi. Dengan membatasi pada biokapasitas internal Pulau Jawa, yaitu tidak memasukkan faktor adanya barang dan jasa yang masuk dan keluar Pulau Jawa, kondisi memburuknya ekologi Pulau Jawa ditemukan dalam penelitian ini. Jadi dalam perhitungan tapak ekologi ini Pulau Jawa diasumsikan tertutup dari dunia luar.

Hasil perhitungan tapak ekologi Pulau Jawa terhadap produk-produk pangan dan energi menunjukkan bahwa tapak ekologi Pulau Jawa tahun 2006 bernilai 3,30 Gha/orang atau 1,85 ha/orang (Tabel 11).

Tabel 11. Tapak Ekologi dan Biokapasitas Pulau Jawa Tahun 2006

\begin{tabular}{|c|c|c|c|c|c|c|c|c|}
\hline \multirow[b]{2}{*}{ Propinsi } & \multicolumn{4}{|c|}{ TAPAK EKOLOGI } & \multicolumn{4}{|c|}{ BIOKAPASITAS } \\
\hline & Gha & ha & $\begin{array}{l}\text { Gha/ } \\
\text { org }\end{array}$ & $\begin{array}{l}\text { ha/ } \\
\text { org }\end{array}$ & Gha & ha & $\begin{array}{l}\text { Gha/ } \\
\text { org }\end{array}$ & $\begin{array}{l}\text { ha/ } \\
\text { org }\end{array}$ \\
\hline DKI Jakarta & 223.756 & 143.945 & 0,03 & 0,02 & 145.619 & 66.152 & 0,02 & 0,01 \\
\hline Jawa Barat & 128.013 .970 & 62.628 .328 & 3,23 & 1,58 & 6.988 .199 & 3.592 .422 & 0,18 & 0,09 \\
\hline $\begin{array}{l}\text { Jawa Tengah } \\
\text { DI }\end{array}$ & 83.157 .246 & 39.108 .697 & 2,59 & 1,22 & 6.526 .577 & 3.254 .412 & 0,20 & 0,10 \\
\hline Yogyakarta & 10.640 .627 & 5.001 .032 & 3,13 & 1,47 & 656.172 & 318.580 & 0,19 & 0,09 \\
\hline Jawa Timur & 65.181 .904 & 31.533 .648 & 1,78 & 0,86 & 8.917 .825 & 4.577 .679 & 0,24 & 0,12 \\
\hline Banten & 10.937 .244 & 5.242 .153 & 1,17 & 0,56 & 2.183.618 & 1.032 .667 & 0,23 & 0,11 \\
\hline Pulau Jawa & 428.617 .037 & 240.810 .362 & 3,30 & 1,85 & 23.630 .513 & 12.006 .751 & 0,18 & 0,09 \\
\hline
\end{tabular}


Tabel di atas menunjukkan bahwa setiap penduduk Pulau Jawa telah menggunakan lahan untuk konsumsi produk pangan dan energi sebesar 1,85 ha atau 3,30 ha dalam standar dunia. Pada saat yang sama kemampuan lahan (pertanian, padang rumput, perairan darat, dan hutan) menyediakan bioproduktif untuk menopang kehidupan tersebut sebesar 0,18 Gha/orang atau 0,09 ha/orang. Keadaan ini mengindikasikan bahwa kapasitas biologis lahan-lahan di Pulau Jawa dalam menyediakan produkproduk yang dikonsumsi oleh penduduk sudah terlampaui (overshoot) sebesar 3,11 Gha/orang atau 1,76 ha/orang (Tabel 12). Menurut Tabel 12, defisit ekologi sudah terjadi pada semua provinsi di Pulau Jawa.

Tabel 12. Defisit Ekologi Pulau Jawa Tahun 2005

\begin{tabular}{lrrrr}
\hline \multirow{2}{*}{ Provinsi } & \multicolumn{4}{c}{ KONDISI EKOLOGI } \\
\cline { 2 - 5 } & \multicolumn{1}{c}{ Gha } & ha & Gha/orang & ha/orang \\
\hline DKI Jakarta & -78.137 & -77.793 & $-0,01$ & $-0,01$ \\
Jawa Barat & -121.025 .771 & -59.035 .906 & $-3,05$ & $-1,49$ \\
Jawa Tengah & -76.630 .669 & -35.854 .285 & $-2,38$ & $-1,11$ \\
DI Yogyakarta & -9.984 .455 & -4.682 .452 & $-2,94$ & $-1,38$ \\
Jawa Timur & -56.264 .079 & -26.955 .969 & $-1,54$ & $-0,74$ \\
Banten & -8.753 .627 & -4.209 .486 & $-0,94$ & $-0,45$ \\
\hline Pulau Jawa & -404.986 .525 & -228.803 .611 & $-3,11$ & $-1,76$ \\
\hline
\end{tabular}

Defisit ekologi dialami oleh semua katagori lahan (pertanian, padang rumput, perairan darat, dan hutan) (Lihat Lampiran 6). Dalam perhitungan ini diperoleh angka positif -berarti terjadi surplus, pada katagori lahan pertanian di DKI Jakarta dan Banten serta hutan pada semua provinsi. Kasus surplus ekologi lahan pertanian di DKI Jakarta dan Banten, terjadi karena produksi pertanian di kedua provinsi tersebut lebih rendah dari kemampuan lahan pertanian (sawah, lading/tegal, dan kebun) tersebut menghasilkan produk-produk pertanian. Akibatnya, konsumsi penduduk terhadap produk pertanian relatif lebih sedikit -tanpa memperhatikan konsumsi produk pertanian dari luar provinsi. Sedangkan kasus surplus ekologi hutan pada masing-masing provinsi disebabkan tidak adanya data konsumsi BBM di tingkat provinsi. Akibatnya perhitungan hanya mempertimbangkan produk kehutanan (kayu-kayuan) untuk katagori lahan hutan. Adapun perhitungan kondisi lahan hutan Pulau Jawa selain mempertimbangkan produk kehutanan, juga memasukkan konsumsi BBM sebagai variabel utama penggunaan energi oleh penduduk Pulau Jawa. Dengan memasukkan konsumsi produk kehutanan dan BBM, telah terjadi defisit hutan di Pulau Jawa.

Hasil perhitungan di atas agak jauh apabila dibandingkan dengan tapak ekologi Indonesia menurut perhitungan Global Footprint Network (data tahun 2003), yakni sebesar 1,1 Gha/orang dengan total biokapasitas sebesar 1,0 Gha/orang (Tabel 13).

Besarnya defisit ekologi Pulau Jawa menurut perhitungan ini (-2,62 Gha/orang) cukup lebih tinggi dari defisit ekologi menurut GFN (data tahun 2003), yakni sekitar -0,1 Gha/orang. Dari sini dapat dipahami bahwa tapak ekologi Pulau Jawa lebih besar dibandingkan tapak ekologi Indonesia. Tanpa memperhatikan perbedaan tahun, Pulau Jawa dapat dinyatakan sebagai pulau dengan tapak ekologi lebih besar 
daripada pulau-pulau lainnya (Pulau Jawa lebih dari angka rata-rata). Sedangkan biokapasitas menunjukkan hal sebaliknya, yaitu biokapasitas Pulau Jawa lebih rendah dibanding pulau-pulau lainnya (biokapasitas Pulau Jawa 0,18 Gha/orang, sedangkan Indonesia 1,0 Gha/orang).

Tabel 13. Tapak Ekologi dan Biokapasitas Indonesia (Data Tahun 2003)

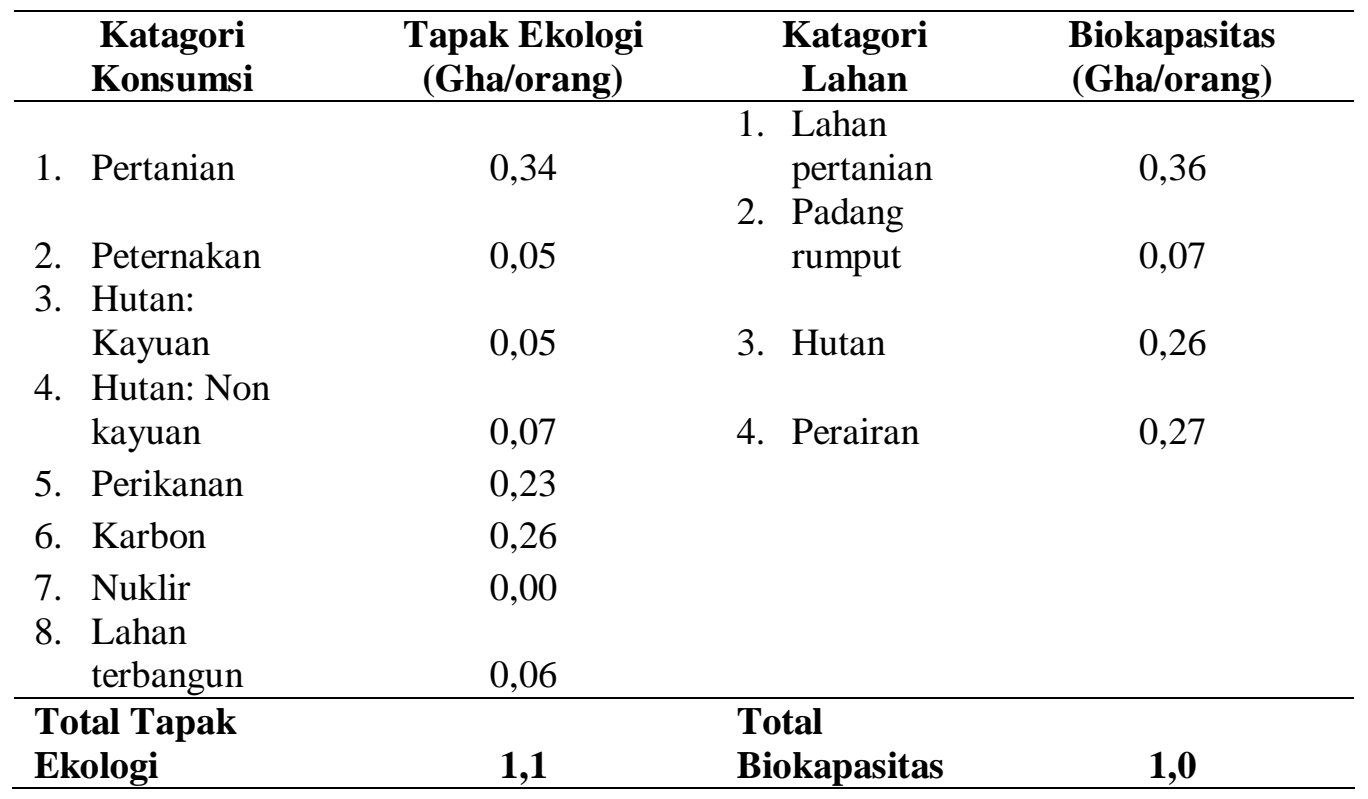

Sumber: Ecological Footprint and Biocapacity (2006 Edition), Global Footprint Network 2006. www.footprintnetwork.org

Apabila dikaitkan dengan indeks tekanan penduduk, hasil perhitungan tapak ekologi Pulau Jawa semakin menguatkan kesimpulan mengenai gejala over population Pulau Jawa atau menurunnya daya dukung Pulau Jawa. Besarnya tapak ekologi Pulau Jawa pada tahun 2006 dibandingkan tapak ekologi Indonesia pada tahun 2003, juga mengindikasikan konsentrasi penduduk Indonesia pada pulau ini. Menurunnya daya dukung Pulau Jawa merupakan kesimpulan dari stagnasi sistem pertanian yang tidak beranjak melakukan perubahan diri dan penurunan kuantitas dan kualitas hutan.

\section{Masa Pemulihan Ekologi Pulau Jawa}

Terdapat dua faktor utama yang turut menentukan keseimbangan tapak ekologi dan biokapasitas. Dua faktor tersebut adalah laju konsumsi bahan pangan dan bukan pangan penduduk sebagai pendorong peningkatan tapak ekologi serta laju rehabilitasi lahan sebagai variabel yang dapat meningkatkan biokapasitas. Pada saat ini laju konsumsi penduduk dapat didekati dengan laju tingkat pengeluaran per kapita sebulan sebagaimana selalu dilansir oleh BPS melalui Susenas. Sementara laju rehabilitasi lahan yang dimaksud adalah upaya memperbaiki kualitas lahan pertanian, perairan, padang rumput, dan hutan. Karena banyaknya faktor yang mempengaruhi perbaikan kualitas jenis-jenis lahan tersebut, serta keterbatasan data yang tersedia, maka estimasi waktu yang diperlukan untuk memulihkan kondisi ekologi Pulau Jawa di sini akan dipergunakan asumsi. Asumsi tersebut adalah: 
1. Identifikasi faktor yang mempengaruhi perbaikan kualitas keempat jenis lahan tersebut dapat disatukan ke dalam satu besaran tertentu sehingga dapat diketahui besar kenaikan dari tahun ke tahun. Misalnya, lahan pertanian diperbaiki dengan menerapkan sistem pertanian dengan input kimiawi rendah; perairan dijaga dengan memperbaiki kondisi DAS, padang rumput diperbaiki dengan perluasan areal, dan hutan dengan reboisasi seperti menambah ruang terbuka hijau. Membaiknya kondisi lahan-lahan tersebut disatukan dalam besaran tertentu, yaitu meningkatnya kesuburan alami lahan pertanian, meningkatnya kualitas air dan biodiversitas ekosistem perairan darat, meningkatnya biodiversitas tumbuhan makanan hewan, dan meningkatnya biodiversitas vegetasi hutan serta kemampuannya dalam menyerap karbon udara.

2. Fungsi kenaikan perbaikan kualitas lahan identik dengan fungsi laju pengeluaran konsumsi. Dengan demikian besar kenaikan perbaikan kualitas lahan dari tahun ke tahun dapat ditetapkan besarannya dengan memperkirakan berapa perbandingannya dengan laju pengeluaran konsumsi penduduk. Misalnya, kenaikan perbaikan kualitas lahan sebesar $75 \%$ dari laju pengeluaran konsumsi berarti akan menurunkan laju peningkatan tapak ekologi sebesar $75 \%$ pada periode tahun tertentu.

3. Laju pengeluaran konsumsi penduduk merupakan fungsi linear dari perkembangan penduduk, karenanya tingkat pengeluaran konsumsi penduduk mengikuti fungsi eksponensial sebagaimana reit perkembangan penduduk.

4. Tingkat pengeluaran konsumsi penduduk dianggap ceteris paribus pada saat tahun awal penghitungan.

Dengan berpedoman pada asumsi tersebut diperoleh lamanya pemulihan Pulau Jawa seperti pada Tabel 14 .

Tabel 14. Lamanya Pemulihan Ekologi Pulau Jawa Dihitung Sejak Tahun 2006

\begin{tabular}{|c|c|c|}
\hline No & $\begin{array}{c}\text { Perbandingan Laju Kenaikan Perbaikan } \\
\text { Kualitas Lahan terhadap Laju } \\
\text { Pengeluaran Konsumsi Penduduk } \\
\text { (8,96\% per tahun) }\end{array}$ & $\begin{array}{c}\text { Lamanya Pemulihan Ekologi } \\
\text { Pulau Jawa (Tahun) }\end{array}$ \\
\hline 1. & $15 \%(1,34)$ & 215,33 \\
\hline 2. & $25 \%(2,24)$ & 129,33 \\
\hline 3. & $50 \%(4,48)$ & 64,66 \\
\hline 4. & $100 \%(8,96)$ & 32,33 \\
\hline
\end{tabular}

Keterangan: laju pengeluaran konsumsi ditetapkan sebesar 8,96\% per tahun, yakni laju pada tahun 2005-2007 sebagai acuan.

Tampak dalam Tabel 14, minimal dibutuhkan waktu untuk mengembalikan kondisi ekologi Pulau Jawa, yakni apabila tidak ada perubahan dalam pola konsumsi penduduk, selama 32,33 tahun. Artinya, paling cepat pada tahun 2038 keadaan Pulau Jawa baru akan seimbang dalam menyediakan biokapasitas untuk seluruh penduduknya. Dengan catatan laju perbaikan kualitas lahan bioproduktif sebesar $8,96 \%$ per tahun. 


\section{KESIMPULAN DAN SARAN}

\section{Kesimpulan}

Berdasarkan penelitian yang di lakukan di Pulau Jawa maka dapat disimpulkan bahwa besarnya jumlah penduduk mengakibatkan tingginya konsumsi akan bahan makanan dan bukan makanan. Kenyataan ini berujung pada tingginya indeks tekanan penduduk terhadap lahan, yakni sebesar 1,80. Ini bisa dipahami karena jumlah penduduk yang terus meningkat sementara ketersediaan lahan cenderung tetap bahkan berkurang, hal ini membuat intensifikasi terhadap lahan menjadi sebuah pilihan yang harus ditempuh. Intensifikasi dan peningkatan aktifitas penduduk inilah yang menjadi faktor penyebab adanya tekanan penduduk (over population). Jika kondisi ini tidak di atasi atau dibiarkan berlanjut, maka akan membawa dampak yang merugikan terutama bagi penduduk di pulau Jawa. Tekanan penduduk akan mempercepat degradasi lahan, sehingga pada titik tertentu produksi bahan pangan akan mengalami penurunan. Tekanan penduduk juga akan berakibat pada rendahnya kualitas hidup penduduk tersebut.

Pada tahun 2006, penduduk Pulau Jawa telah menggunakan 3,30 Gha/orang atau 1,85 ha/orang untuk memenuhi seluruh aktivitasnya. Padahal kapasitas Pulau Jawa menampung penduduk sebesar 0,18 Gha/orang atau 0,09 ha/orang. Keadaan demikian mengakibatkan Pulau Jawa telah terlampaui atau mengalami defisit ekologi. Waktu yang diperlukan untuk memulihkan keadaan ini minimal diperlukan 32,33 tahun.

\section{Saran}

Ada beberapa langkah yang dapat ditempuh atau diterapkan oleh pemerintah dalam mengurangi tekanan penduduk ini, yaitu:

1. Membuat peraturan yang akan memperketat migrasi masuk ke pulau Jawa.

2. Pembangunan yang lebih merata di luar Pulau Jawa, sehingga angkatan kerja dan aktifitas kegiatan ekonomi dapat dialihkan ke luar Jawa.

3. Meningkatkan daya dukung eksternal.

4. Melaksanakan pembangunan yang ramah lingkungan serta pola hidup yang sederhana oleh masyarakat melalui upaya-upaya yang dapat menghemat konsumsi energi.

5. Melakukan upaya-upaya yang dapat mempercepat pemulihan biologis dari lingkungan, misalnya dengan cara melakukan reboisasi dan penghijauan.

\section{DAFTAR PUSTAKA}

Anonim. 2006. Ecological Footprint: Overview. Available from: http://www.footprintnetwork.org/gfn sub.php?content=footprint overview (Last updated: 10/17/2006) at March 20, 2007.

Bharadwaj, L.K.1992. Human Ecology and The Environment dalam E.F Borgatta and M.L Borgatta (eds) Encyclopedia of Sociology. Volume 2. Macmillan Publishing Company: New York. 
Boeke, J.H. 1942. The Structure of Netherlands Indies Economy. International Secreatariat Institute of Pacific Relations: New York.

BPS. 2001. Penduduk Indonesia Hasil Sensus Penduduk Tahun 2000. Seri L.2.2. Jakarta-Indonesia.

[BPS]. 2007. Statistik Indonesia 2007. BPS: Jakarta.

FAO. 1986. Population and The Labour Force in Rural Economies. Food and Agriculture Organization of Unite Nations : Rome.

Geertz, C. 1956. The Social Context of Economic Change: An Indonesian Case Study. Cambridge: Centre for International Studies, Massachusetts Insitute of Technology.

Global Footprint Network, 2005. National Footprint and Biocapacity Accounts, 2005 Edition. Available at http://www.footprintnetwork.org.

Hawley, A.H. 1950. Human Economy. New York: The Ronald Press Company.

Huxley, J. 1955. World Population dalam F.W Notestein (ed.) Three Essays on Population. A Mentor Book, 1960: New York.

Jones, G.W. 1993. Population, Environment, and Sustainable Development in Indonesia. Majalah Demografi Indonesia. XX, 40: 1-20.

Malthus. R.T. 1930. A Summary View of the Principles of Population dalam F.W. Notestein (ed). Three Essays on Population. A Mentor Book, 1960: New York.

McDonald, Garry and Murray Patterson. 2003. Ecological of New Zealand and Its Regions. Environment Reporting on September. Ministry for The Environment of New Zealand. Available from: http://www.mfe.govt.nz/publications/ser/eco-footprint-sep03/eco-footprintcover-exec-summary.pdf. At March 20, 2007.

Lenzen M and Murray. 2001. Modified Ecological Footprint Method and Its Application. Ecological Economic. 37 (2). pp. 229-255. .2003. The Ecological Footprint - Issues and Trends. ISA Research Paper 01-03. The University of Sidney. Sidney-Australia. Available from:

http://www.isa.org.usyd.edu.au/publications/documents/Ecological Footsprint _Issues_and_Trend.pdf at March 20, 2007.

Lucas, David and Paul Meyer (eds). 1994. Beginning Population Studies. Australian National University. National Centre for Development Studies.

Soemarwoto, O. 1985. A Quantitative Model of Population Pressure and Its Potensial Use of Development Planning, Majalah Demografi Indonesia. XII, 24: 1-15.

Soemarwoto, Otto 1994. Ekologi, Lingkungan Hidup dan Pembangunan. Djambatan: Jakarta. 
Soemarwoto, O. 1995. Kependudukan dan Lingkungan Hidup, Warta Demografi. Th 25, No. 6.

Ranganathan, J. And Daily, G.C. 2003. Carrying Capacity dalam P. Demeny an McNicoll 9Eds) Encyclopedia of Population. Macmillan Reference USA: New York.

Rees, W. and Wackernagel, M.:1996. Our Ecological Footprint. New Society Publishers: Gabriola Island.

Rusli, Said 1996. Pengantar Ilmu Kependudukan. LP3ES: Jakarta.

Orians, C.A and Skumanich, M. 1997. The Population Environment Connection. Battelle Seatle Research Center: Seatle.

Venetoulis, Jason and Talberth, John.: 2006, 'Net Primary Productivity as the Basis for Ecological Footprint Analysis,' submitted, Jan. 2006.

Waekernagel M, Lewan L, and Hansson CB. 1999. Evaluating The Use of Nature Capital With Ecological Footprint. Ambio 28(7). pp. 604-612.

Wackernagel M, Chad Mossfreda, Dan Moran, Paul Wermer, Steve Goldfinger, Dian Demling, Michael Murray. 2005. National Footprint and Biocapacity Account 2005: The Underlying Calculation Method. A paper build May 25, 2005. Available from:

http://www.footprintnetwork.org/gfn sub.php?content=datametho ds part, methodology paper, at March 20, 2007.

Zimmermann, 1964. dalam Henry L. Hunker (ed.) Introduction ro World Resources. Harper \& Row: New York. 


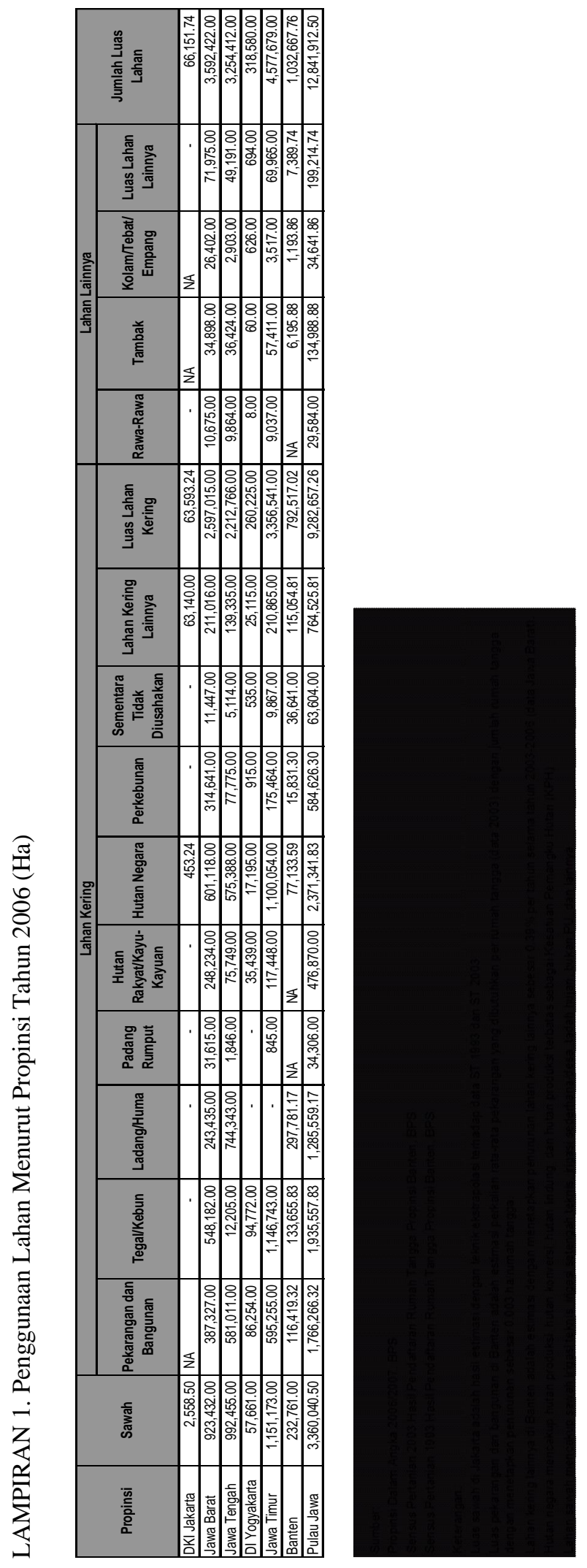

Sodality: Jurnal Transdisiplin Sosiologi, Komunikasi, dan Ekologi Manusia Vol. 3, No. $12009 \mid 107$ 

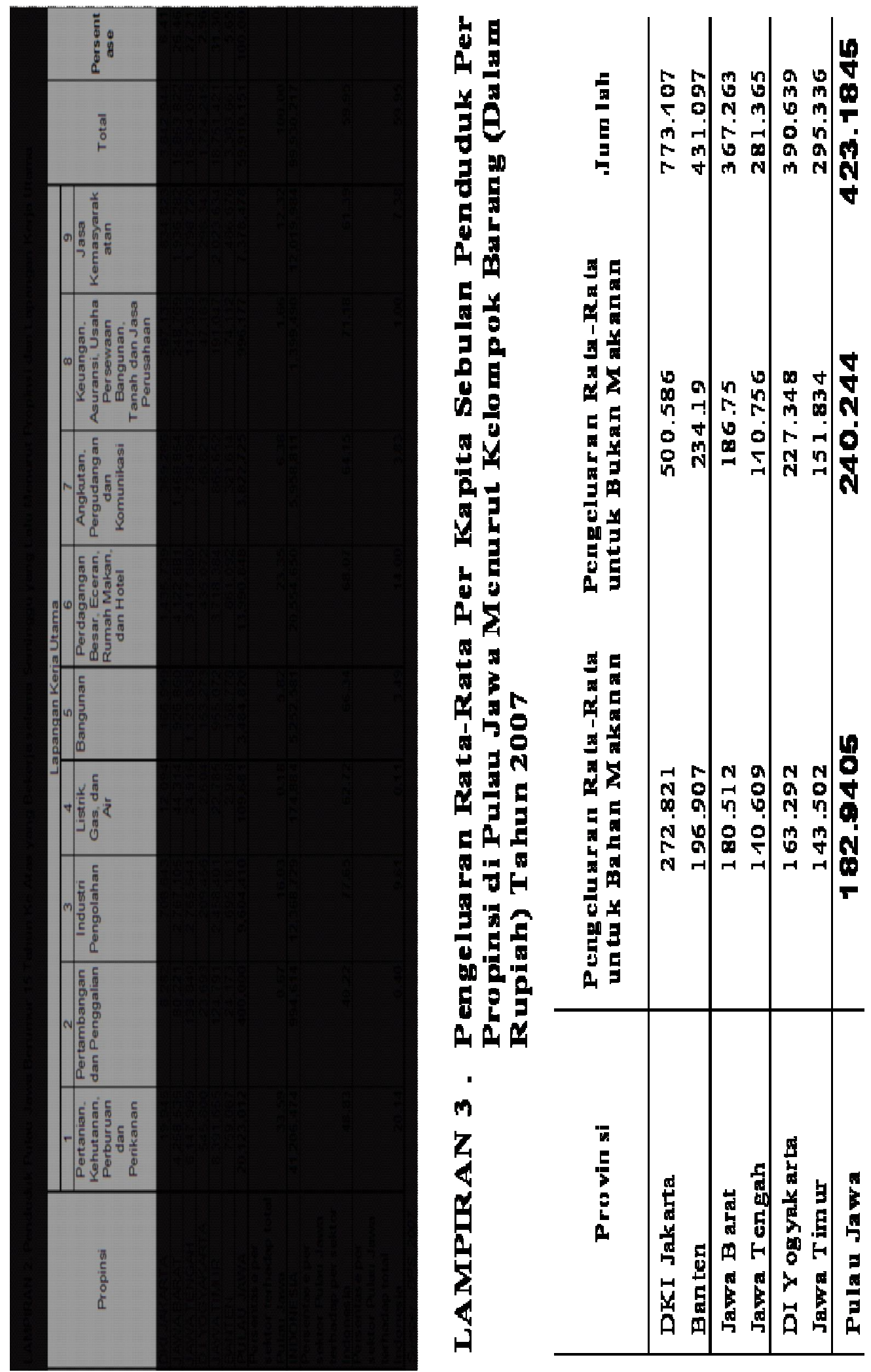

108 Rusli, Said et.al. Tekanan Penduduk, Overshoot Ekologi Pulau Jawa, dan Masa Pemulihannya 


\section{LAMPIRAN 4. Tingkat Kenaikan Setahun Pengeluaran Rata-Rata Per Kapita Sebulan 2002-2005 dan 2005-2007}

\begin{tabular}{|l|c|c|c|c|c|}
\hline \multirow{2}{*}{$\begin{array}{l}\text { Provinsi - Province } \\
\end{array}$} & \multicolumn{3}{|c|}{$\begin{array}{c}\text { Pengeluaran Rata-Rata Per Kapita } \\
\text { Sebulan (Rp) }\end{array}$} & \multicolumn{2}{c|}{$\begin{array}{c}\text { Tingkat Kenaikan } \\
\text { Setahun \% } \\
\text { Annual Incremental } \\
\text { Ronthly average Expenditure Per Capita }\end{array}$} \\
\cline { 2 - 6 } & 2002 & 2005 & 2007 & $\begin{array}{c}2002- \\
2005\end{array}$ & $2005-2007$ \\
\hline DKI Jakarta & $\mathbf{4 8 1 . 5 8 5}$ & $\mathbf{6 5 8 . 7 6 4}$ & $\mathbf{7 7 3 . 4 0 7}$ & $\mathbf{1 1 . 0 1}$ & $\mathbf{8 . 3 5}$ \\
\hline Jawa Barat & $\mathbf{2 0 9 . 0 7 8}$ & $\mathbf{2 9 6 . 2 8 3}$ & $\mathbf{3 6 7 . 2 6 3}$ & $\mathbf{1 2 . 3 2}$ & $\mathbf{1 1 . 3 4}$ \\
\hline Jawa Tengah & $\mathbf{1 7 2 . 6 8 6}$ & $\mathbf{2 2 8 . 6 0 2}$ & $\mathbf{2 8 1 . 3 6 5}$ & $\mathbf{9 . 8 0}$ & $\mathbf{1 0 . 9 4}$ \\
\hline $\begin{array}{l}\text { Daerah Istimewa } \\
\text { Yogyakarta }\end{array}$ & $\mathbf{2 3 1 . 8 8 5}$ & $\mathbf{3 6 7 . 2 9 7}$ & $\mathbf{3 9 0 . 6 3 9}$ & $\mathbf{1 6 . 5 7}$ & $\mathbf{3 . 1 3}$ \\
\hline Jawa Timur & $\mathbf{1 8 6 . 6 6 5}$ & $\mathbf{2 5 3 . 1 8 3}$ & $\mathbf{2 9 5 . 3 3 6}$ & $\mathbf{1 0 . 6 9}$ & $\mathbf{8 . 0 0}$ \\
\hline Banten & $\mathbf{2 6 0 . 2 3 7}$ & $\mathbf{3 4 3 . 5 3 8}$ & $\mathbf{4 3 1 . 0 9 7}$ & $\mathbf{9 . 7 0}$ & $\mathbf{1 2 . 0 2}$ \\
\hline \multicolumn{1}{|c|}{ Indonesia } & $\mathbf{2 0 6 . 3 3 6}$ & $\mathbf{2 8 6 . 7 4 1}$ & $\mathbf{3 5 3 . 4 2 1}$ & $\mathbf{1 1 . 5 9}$ & $\mathbf{1 1 . 0 2}$ \\
\hline
\end{tabular}

Keterangan/ note:

1) Hanya dilakukan pengumpulan data kor di ibukota Provinsi/ Only core data were collected from the provience's capital

2) Tidak digunakan untuk estimasi angka Indonesia/ Excluded in the Indonesia estimation

3) Masih merupakan bagian dari Provinsi Riau / Not yet separated from Riau

4) Masih merupakan bagian dari Provinsi Sulawesi Selatan/ Not yet separated from Sulawesi Selatan

5) Masih merupakan bagian dari Provinsi Papua/ Not yet separated form papua

6) Terjadi penurunan pengeluaran ke kondisi normal setelah terjadi Tsunami/ Expenditure decreased after Tsunami 


\section{Persentase Pengeluaran Rata-Rata Per kapita Sebulan untuk Makanan dan Bukan Makanan menurut Provinsi Tahun 2002, 2005, dan 2007 /}

\begin{tabular}{|l|c|c|c|c|c|c|}
\hline \multirow{2}{*}{ Provinsi - Province } & \multicolumn{3}{|c|}{ Konsumsi Makanan } & \multicolumn{3}{c|}{$\begin{array}{c}\text { Konsumsi Bukan Makanan } \\
\text { Consumption of Non Food }\end{array}$} \\
\cline { 2 - 7 } & 2002 & 2005 & 2007 & 2002 & 2005 & 2007 \\
\hline DKI Jakarta & $\mathbf{4 0 . 5 3}$ & $\mathbf{3 7 . 7 2}$ & $\mathbf{3 5 . 2 8}$ & $\mathbf{5 9 . 4 7}$ & $\mathbf{6 2 . 2 8}$ & $\mathbf{6 4 . 7 2}$ \\
\hline Jawa Barat & $\mathbf{5 9 . 1 6}$ & $\mathbf{5 0 . 4 2}$ & $\mathbf{4 9 . 1 5}$ & $\mathbf{4 0 . 8 4}$ & $\mathbf{4 9 . 5 8}$ & $\mathbf{5 0 . 8 5}$ \\
\hline Jawa Tengah & $\mathbf{5 9 . 3 1}$ & $\mathbf{5 2 . 6 1}$ & $\mathbf{4 9 . 9 7}$ & $\mathbf{4 0 . 6 9}$ & $\mathbf{4 7 . 3 9}$ & $\mathbf{5 0 . 0 3}$ \\
\hline $\begin{array}{l}\text { Daerah Istimewa } \\
\text { Yogyakarta }\end{array}$ & $\mathbf{5 0 . 4 1}$ & $\mathbf{4 0 . 1 3}$ & $\mathbf{4 1 . 8 0}$ & $\mathbf{4 9 . 5 9}$ & $\mathbf{5 9 . 8 7}$ & $\mathbf{5 8 . 2 0}$ \\
\hline Jawa Timur & $\mathbf{5 7 . 8 7}$ & $\mathbf{5 0 . 7 5}$ & $\mathbf{4 8 . 5 9}$ & $\mathbf{4 2 . 1 3}$ & $\mathbf{4 9 . 2 5}$ & $\mathbf{5 1 . 4 1}$ \\
\hline Banten & $\mathbf{5 6 . 6 2}$ & $\mathbf{4 8 . 9 8}$ & $\mathbf{4 5 . 6 8}$ & $\mathbf{4 3 . 3 8}$ & $\mathbf{5 1 . 0 2}$ & $\mathbf{5 4 . 3 2}$ \\
\hline Indonesia & $\mathbf{5 8 . 4 7}$ & $\mathbf{5 1 . 3 7}$ & $\mathbf{4 9 . 2 4}$ & $\mathbf{4 7 . 1 8}$ & $\mathbf{4 8 . 6 3}$ & $\mathbf{5 0 . 7 6}$ \\
\hline
\end{tabular}

Keterangan/ note:

1. Hanya dilakukan pengumpulan data kor di ibukota Provinsi/ Only core data were collected from the provience's capital

2. Tidak digunakan untuk estimasi angka Indonesia/ Excluded in the Indonesia estimation

3. Masih merupakan bagian dari Provinsi Riau / Not yet separated from Riau

4. Masih merupakan bagian dari Provinsi Sulawesi Selatan/ Not yet separated from Sulawesi Selatan

5. Masih merupakan bagian dari Provinsi Papua/ Not yet separated form рариа 


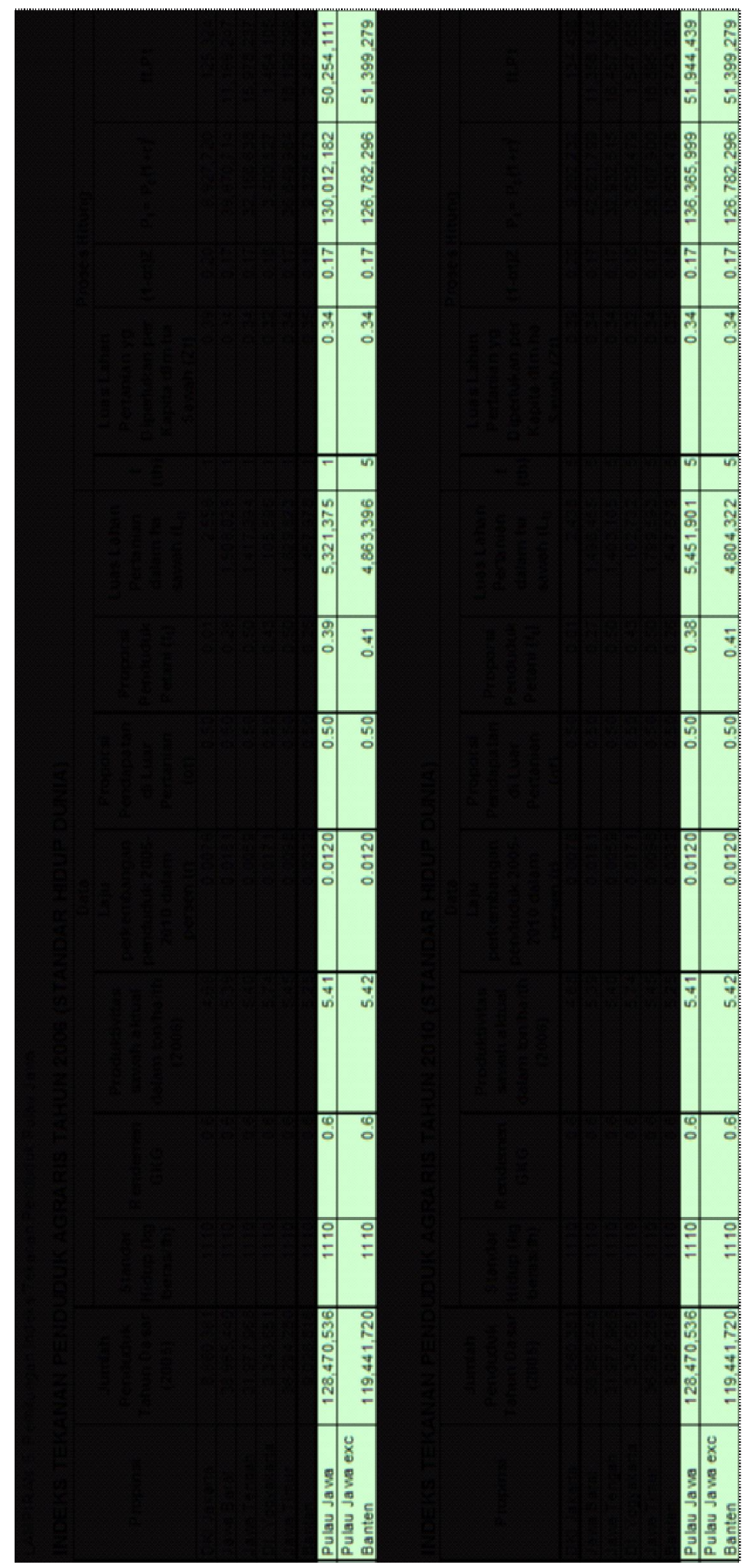

Sodality: Jurnal Transdisiplin Sosiologi, Komunikasi, dan Ekologi Manusia Vol. 3, No. 12009 | 111 
112 | Rusli, Said et.al. Tekanan Penduduk, Overshoot Ekologi Pulau Jawa, dan Masa Pemulihannya 